\title{
Impact of Hydraulic fracturing on Mineralogy on Change in Micro and Nano Porosity and Permeability of Shales
}

\section{Di Zhang}

New Jersey Institute of Technology

Jay Meegoda ( $\nabla$ meegoda@njit.edu )

New Jersey Institute of Technology

Bruno Goncalves da Silva

New Jersey Institute of Technology

Liming HU

Tsinghua University

\section{Research Article}

Keywords: Shale gas extraction, Hydraulic fracturing, Shale Softening, Mineralogy of shale, Micro and Nano Pores, Permeability reduction

Posted Date: April 15th, 2021

DOI: https://doi.org/10.21203/rs.3.rs-420936/v1

License: (9) This work is licensed under a Creative Commons Attribution 4.0 International License. Read Full License 


\section{Impact of Hydraulic fracturing on Mineralogy on Change in Micro and Nano Porosity and Permeability of Shales}

Di Zhang, ${ }^{1}$ Jay N. Meegoda, ${ }^{1,2, *}$ Bruno M. Goncalves da Silva ${ }^{1,}$ and Liming $\mathrm{Hu}^{2}$ ${ }^{1}$ Department of Civil \& Environmental Engineering, New Jersey Institute of Technology ${ }^{2}$ Department of Hydraulic Engineering, Tsinghua University *Corresponding author Meegoda@njit.edu

Abstract

Hydraulic fracturing is widely applied to economical gas production from shale reservoirs. Still, the gradual swelling of the clay micro/nanopores due to retained fluid from hydraulic fracturing causes a gradual reduction of gas production. Four different gas-bearing shale samples were investigated to quantify the expected shale swelling due to hydraulic fracturing. These shale samples were subject to heated deionized (DI) water at $100^{\circ} \mathrm{C}$ temperature and $1.2 \mathrm{MPa}$ pressure in a laboratory reactor for 72 hours to simulate shale softening. The low-temperature nitrogen adsorption and density measurements were performed on the original and treated shale to determine the micro and nanopore structure change. The micro and nanopore structures changed during shale swelling, and the porosity decreased after shale treatment. The porosity decreased by $4 \%$ for clayey shale, while for well-cemented shale the porosity only decreased by $0.52 \%$. The findings showed that the initial mineralogical composition of shale plays a significant role in the swelling of micro and nanopores and the pore structure alteration due to retained fluid from hydraulic fracturing. A pore network model was used to compare the permeability due to shale softening. The permeability results show a reduction from $3.76 \mathrm{E}-16 \mathrm{~m}^{2}$ to $2.62 \mathrm{E}-17 \mathrm{~m}^{2}$ after treatment based on the simulations.

Keywords: Shale gas extraction, Hydraulic fracturing, Shale Softening, Mineralogy of shale, Micro and Nano Pores, Permeability reduction 


\section{Introduction}

During the past decades, due to the development of multi-stage hydraulic fracturing and horizontal promising drilling technologies, worldwide unconventional shale gas production in low permeability shale reservoirs has increased [1]. According to the U.S. Energy Information Administration (EIA), U.S. shale gas production accounts for $50 \%$ of total natural gas production [2]. Hydraulic fracturing involves the injection of high-pressure fracturing fluid into the shale formation to produce a complex fracture network, facilitating the extraction of adsorbed or stored shale gas stored in micro and nanopores. Though approximately $50 \%$ of the fracturing fluid is recovered after hydraulic fracturing, the balance is retained in the shale formation. These trapped fracturing fluids interact with the shale formation and reduce the permeability and hence the gas productivity of the shale formation [3].

Although the current hydraulic fracturing technology for shale gas production has been widely used, the geochemical reactions and physical changes due to the shale-hydraulic fracturing fluid reaction and the factors contributing to those reactions are not well understood. Several studies have shown swelling of shale due to the interaction of retained and fracturing fluid with clays in shale. Johnston and Beeson [4] analyzed the permeability of more than 1,200 oil sand samples from 107 wells in 43 zones. They showed that approximately $70 \%$ of the sands showed significant and distinct permeability change due to injected freshwater. Morris et al. [5], based on flood tests on reservoir cores containing $8 \%$ swelling clays, showed that the average permeability decreased by $92.5 \%$. Goldenberg et al. [6] showed a reduction in 
porosity due to a logarithmic decrease in overall connectivity of highly reactive smectite minerals.

Due to retained fluid from hydraulic fracturing, exchangeable cations between clay layers of shale formations are hydrated, and the gap between clay layers is increased. Fink et al. [7], Krishna Mohan et al., [8], Norrish [9], Zhang, and Low [10] have shown that the two active pathways of clay swelling and hence potential porosity reduction are crystalline and osmotic swelling. Wilson et al. [11] showed the swelling of North Sea sandstone formation due to clay content in the mineralogy. Davy et al. [12] showed that for poorly connected sedimentary rocks with low porosities ranging from $1 \%$ to $5 \%$, fractures could heal when in contact with fracturing fluids.

Clay swelling hinders gas flow and reduces the effective permeability of shale $[13,14]$. Simultaneously, hydration weakens the binding of mineral particles, thereby further decreasing fracture aperture and hence hydraulic conductivity. Although laboratory-scale water-clay interaction experiments provide valuable preliminary data on the physical and chemical interactions between shale and fracturing fluid, most of these absorption experiments were performed at low temperatures and low pressures $[5,15]$. Field shale reservoirs are usually at high temperatures and subject to high pressures. Several researchers have performed high temperatures and high-pressure laboratory shale softening studies to simulate the processes that occur in reservoirs. Du et al. [16, 17] used deionized water for 48 hours without heating or applying pressure to soften the shale and degradation of mechanical properties after treatment. However, water-clay interaction will be different for actual natural gas reservoirs 
subjected to high temperature and pressure. Wu and Sharma [18] showed that carbonate-acid reactions could be another reason for the porosity change for the interaction of shale formations with slickwater containing a mild acid solution of $\mathrm{pH}$ ranging from 5.6-6.8. Sun et al. [19] used simulated slick water with a 1\% clay-control agent at $100^{\circ} \mathrm{C}$ and $50 \mathrm{MPa}$ for $72 \mathrm{~h}$ to simulate site conditions. The typical composition of slickwater is not freely known and is a trade secret in the fracturing industry. Hence, it is not easy to quantify and standardize additives to simulate actual site conditions for shale softening experiments. Therefore, clay control agents, along with $\mathrm{pH}$ controllers, should be eliminated to simplify the measurements. Hence, de-ionized water is used in this research to investigate the clay-swelling.

The primary objective of this study is to identify the impact of mineralogy on the change in micro and nano porosity of shale during hydraulic fracturing, particularly due to the interaction between the fracturing fluid and the shale. The clay-water reaction is a dynamic mechanism, with several control factors leading to variable test outcomes. As a result, a number of high-temperature and high-pressure shale immersion tests have been undertaken to investigate the impact of water-based drilling fluid on the physical properties of gas-bearing formations. Subsequently, low-pressure nitrogen absorption-desorption (BET) experiments, porosity, and density tests were performed on four different shales to measure variations in the distribution of pore sizes and porosity. The final purpose of this analysis was to measure the decline in shale gas production over time by quantifying the shift in pore structure and reduction in shale permeability due to the association of hydraulic drilling fluid with 
various mineral compositions of shale, resulting in shale softening. Pore network model simulations of the permeability decline in shale formations were performed with softened shale structure and the declining trend was correlated to the shale softening process.

\section{Materials and Methods}

\subsection{Sample preparation}

The clay-rich shale is extremely sensitive to water due to its tendency to react with moisture. Drying and cracking of a shale sample are encountered if in contact with the moisture in the environment. Hence, cores samples used in this research were carefully stored in containers to provide a moisture-free and constant-pressure environment before the softening experiments [20].

Samples of Hayneville, Longmaxi, Eagle Ford, and Opalinus shale formations were cut into smaller pieces using a low-speed precision cutter (model type-minitom manufactured by Struers). This machine allows producing accurate $1 \mathrm{~cm}^{3}$ cubic shale samples. A cooling liquid of pure ethanol is used to cool the cutter instead of water to prevent water interaction with the shale before the treatment. To fit the hydrothermal reactor (shale treatment reactor), the shale sample size has to be smaller than $1 \mathrm{~cm} * 1 \mathrm{~cm} * 1 \mathrm{~cm}$ size. Several powder samples were also prepared before the treatment from four shale samples. The powder samples were prepared using the grinding machine (model type Brinkman manufactured by Restsch), which allows a sufficient amount of 80-100 mesh size for BET tests. 


\subsection{Shale Treatment}

The shale treatment experiment was performed using a specially designed test setup as shown in Figure 1. The main component of the test setup consists of a hydrothermal reactor. High pressure was supplied using a liquid nitrogen tank for this core treatment chamber, and the hydrothermal reactor was immersed in a constant temperature water bath. Before the treatment test, the setup connections were checked because each shale sample has to be inside the chamber for three days to achieve the softening.

Furthermore, before the tests, the whole setup was checked for leaks to ensure it is fully sealed. The treatment chamber was filled with DI water, and the original cubic shale was fully immersed in the simulated fracturing fluid. A 1200 psi pressure was applied to the hydrothermal reactor, and the reactor was kept inside a $100^{\circ} \mathrm{C}$ constant temperature water bath for 72 hours to simulate the actual field conditions [21, 22, 23].

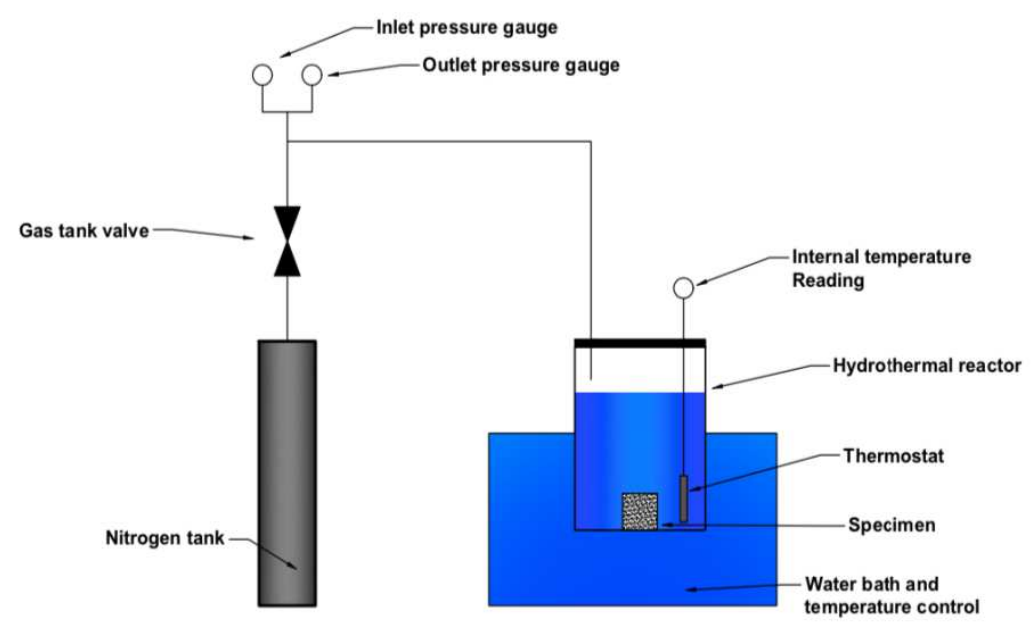

Figure 1. Shale Treatment Setup

In order to prevent the water evaporation from the water bath, it was covered using a 
plastic tarp during the test. After the test, the shale sample was placed inside an oven at $70^{\circ} \mathrm{C}$ to control humidity and moisture 24 hours before BET analysis.

In this research, shale samples will be subject to de-ionized water at $1200 \mathrm{psi}$ and $100^{\circ} \mathrm{C}$ for 72 hours to simulate shale softening. There are five main reasons for the use of deionized water, which are summarized below:

1. The concentration of electrolytes in water can reduce the potential swelling by reducing the diffuse double layer (DDL) [24].

2. The high salt concentration in slickwater can affect the physical properties of clay by causing fine particles to bind together to aggregates or flocculate. Flocking can reduce surface area and decrease free swell and swell pressure [25].

3. The swell potential can decrease with cation exchange between water and clay and prevent the entry of water between the layers [26]. The DDL thickness decreases with salt concentrations leading to the collapse of the clay structure and reducing swelling potential [27].

4. Also, high sodium ion concentration can cause divalent ions such as calcium, which appear to lower DDL in water samples, to be replaced. Therefore, the swell potential decreases with an increased sodium concentration in the slickwater [28].

5. The high temperature and pressure have a significant impact on shale-fluid interactions, which control shale treatment. The addition of chemicals will also increase the rate of mineral dissolution, intensified by high temperatures, 
leading to the breakdown of shale structure and integrity.

Hence, chemicals should be excluded when investigating the pure clay interactions in the shale formations.

\subsection{XRD Measurements}

The X-ray diffraction (XRD) data from four shale samples were used to determine the mineralogy. The mineralogy study is critical to explain the shale softening mechanism based on the clay content of shale. With higher clay contents in a shale formation, a more significant clay-water reaction is expected [29, 30]. Also, clay content varies over a wide range in different formations; hence the determination of clay content is essential to quantify the degree of shale softening. The carbonates may also contribute to shale softening. Hence, the mineralogy study included the quantification of both clay and carbonate contents using XRD tests. Thus, XRD was performed before and after the treatment tests for all shales.

The original and treated shale samples were cleaned, dried, and grounded to a size smaller than $120 \mu \mathrm{m}$ to be used for mineralogical analysis. The same procedure was followed for treated shale. A copper source of $40 \mathrm{kV}$ and $40 \mathrm{~mA}$ was used for the XRD, and the shale powders before and after treatment were subjected to diffraction angles (20) between $5^{\circ}$ and $60^{\circ}$ at a scan rate of $1^{\circ} / \mathrm{min}[31]$.

\subsection{BET Measurements}

The BET analysis aims to determine the absorption and desorption pattern of powder samples, in this case, shale before and after treatment, using the Autosorb machine 
(model type Autosrob-iQ manufactured by Quantachrome Instruments). All test samples were first dried in a vacuum for 12 hours under a constant temperature of $150^{\circ} \mathrm{C}$ before BET tests. The pore volume was determined using the Density Functional Theory (DFT) model [32, 33, 34].

After 12 hours of degassing and full isotherm gas sorption test, both sample powder before and after shale treatment were tested under the same conditions, including degassing pressure and temperature, loading condition, and same liquid $\mathrm{N}_{2}$. Finally, based on the raw data, the porous media-absorption and desorption graphs for four shale samples before and after treatment were obtained.

\section{Pore Network Model for the Simulation of Shale Permeability based on Pore}

\section{Structure}

The shale softening effect will have an enormous impact on the permeability and hence the shale gas production. Once the pore structure of treated or untreated shale is known, the pore network model can predict the shale permeability to quantify the impact of shale softening.

The equivalent pore network model is a simplified calculation model for porous media. Its structure is relatively simple, which can significantly reduce the calculation's complexity and calculate the seepage transport phenomena in porous media $[35,36,37]$. Therefore, the pore network will be used to predict the shale permeability.

As shown in Figure 2, the pores in this model are spheres, and the pore throats are cylindrical. The pores are connected by pore throats. A pore can connect up to 26 pore 
throats. The number of pore throats connected to a given pore is called the coordination number. The average coordination number of all pores in the model is called the average coordination number of the model. The distance between the sphere centers of two adjacent pores is called the unit length. The resulting model can easily simulate porous media with different characteristics by setting different cell lengths, pore radius, pore throat radius, and coordination number.

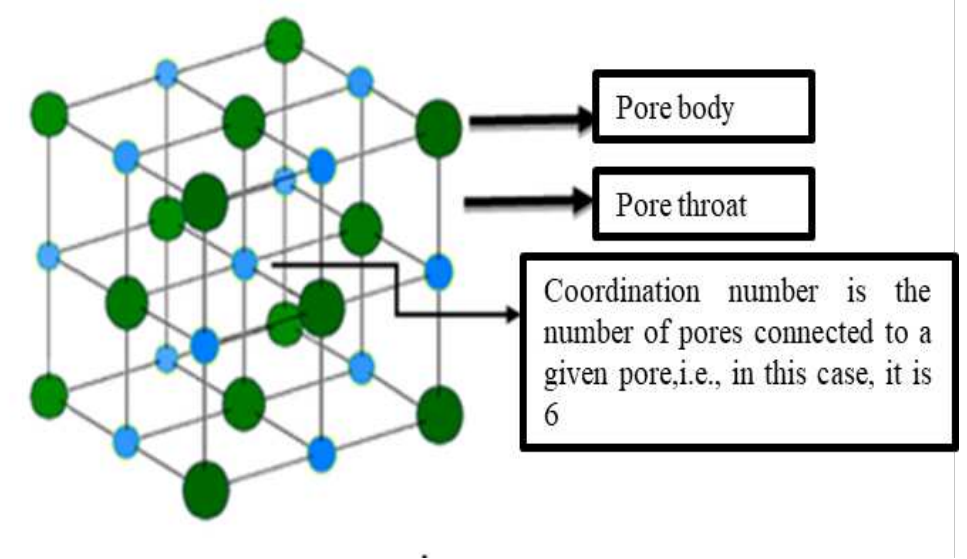

Figure 2. Schematic of each component

To construct the equivalent pore network as described above, the following six key model parameters are required:

Pore radius ( $\mathrm{Rp})$ and its distribution: The pore radius represents the size of the pores that are large cavities throughout the geological media.

Pore throat radius (Rth) and its distribution: The throat radius represents the size of the seepage channel between the pores. Since any fluid migration between the pores must flow through the throat, the throat size directly affects the entire geological media's seepage characteristics.

Coordination number (b) and its distribution: The pore coordination number 
represents the connectivity between pores. For a geological media with high permeability, such as sand, one pore may be connected to multiple surrounding pores, and hence the coordination number is high. For a geological media with low permeability, such as shale, the pore coordination number is relatively small.

Porosity (n): The porosity represents the proportion of the void in the geological media. Here, the voids include all the pores and throats, including dead pores and corresponding pore throats.

Characteristic length (L): $\mathrm{L}$ is a concept introduced in an equivalent pore network representing the length of the mesh, which is the distance between adjacent pores.

Swelling ratio(s): $\mathrm{S}$ is defined as $\mathrm{r}_{\text {th(swelled) }} / \mathrm{r}_{\text {th(original). }} \mathrm{S}$ is a concept introduced in the pore network model as an indicator to show different stages of the softening in the shale matrix.

Swell layer (E): E is another concept introduced in the pore network model to account for shale softening. This factor also serves as an indicator that controls the swelling stages. At an early stage, the swell layer would be the first layer in contact or exposed to hydraulic fracturing. Then it would propagate inwards.

After determining the model size, model construction can be divided into the following steps:

(1) Generation of pore radius.

(2) Pore connection generation.

(3) Use the double-labeling method to eliminate all isolated pores in the equivalent pore network model. 
(4) After the original network was established, each of the parameters was stored.

Now assign the newly introduced swelling factors (swelling layers and swelling ratio) to the original constructed model.

(5) The swelled pore throats will result in the reduction of porosity as well. As the swelling continues, the reduction of porosity would continue. Each time step, the swelled porosity would be calculated.

(6) After the calculation of the porosity, the swelled pore network would repeat from Step (1) to Step (4) until the new network is entirely constructed.

The flow chart is shown in Figure 3, and theory details are included in the supplementary document:

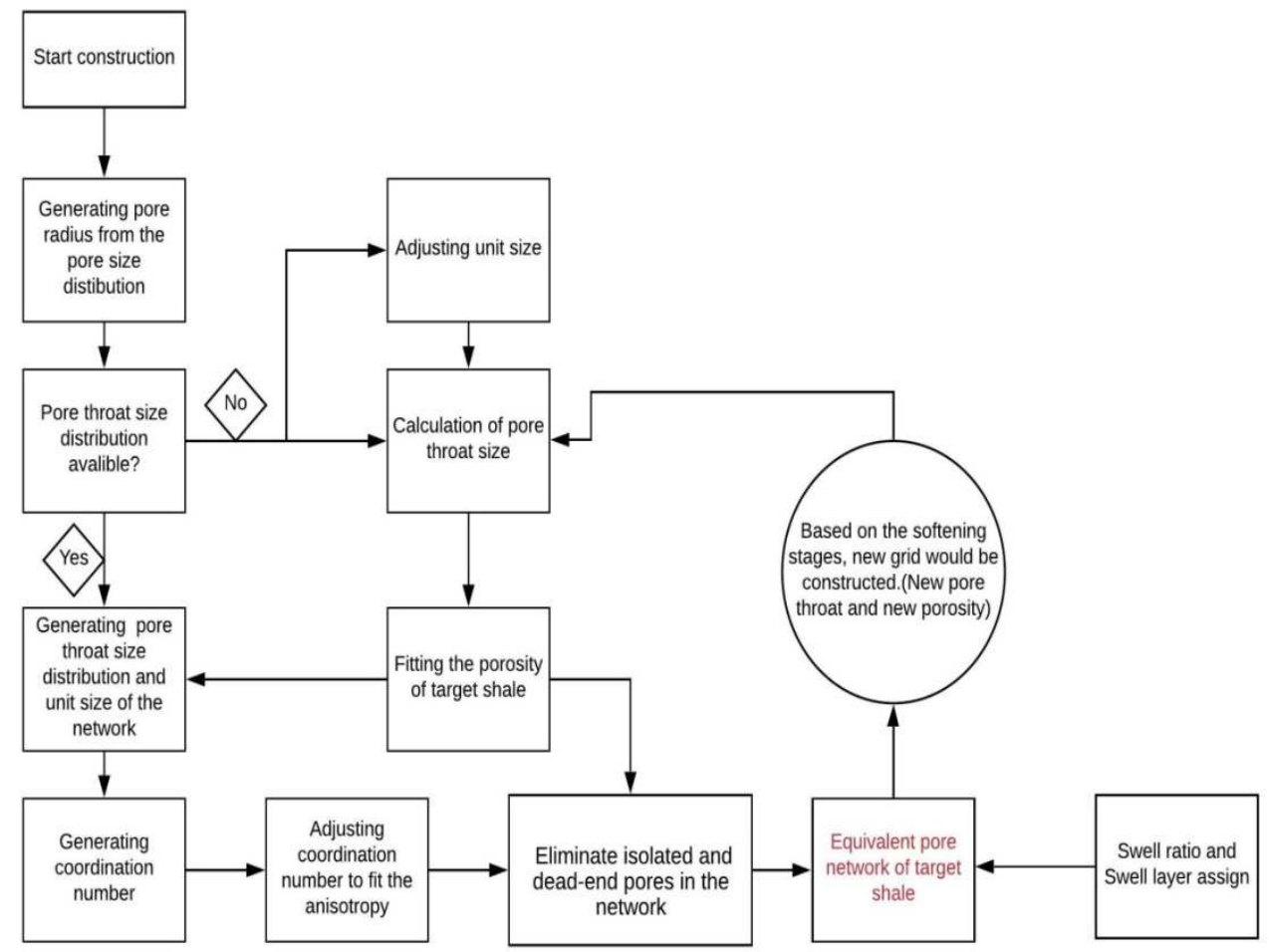

Figure 3. Flowchart of constructing swelling pore network model

\section{Test Results}

Before the treatment test, the density in $\mathrm{g} / \mathrm{cm}^{3}$ of each shale was determined to be 2.29 
for Opalinus, 2.53 for Haynesville, 2.58 for Longmaxi, and 2.43 for Eagle Ford. The sample of each shale was cut into $1 \mathrm{~cm}^{3}$ using a low-speed precision cutter manufactured by Struers. Drying and cracking of a shale sample will be encountered if in contact with the water in the environment, so the cores will be stored in containers to provide a water-free and constant-pressure. Finally, the mass of each $1 \mathrm{~cm}^{3}$ will be measured at room temperature, and density will be calculated using the information.

\subsection{Minerology of Shale}

The XRD results show the peak value for each crystalline material over the scanning angles. By matching the database of known crystalline patterns, one can quantify the mineralogy of a particular powder or solid using the Rietveld method [38, 39, 40, 41]. Figure 4 shows the XRD results for Haynesville shale. Using high-score-plus, which is the advanced XRD data handling software, the quantification of mineralogy can be summarized into a pie chart for Haynesville shale, as shown in Figure 5.

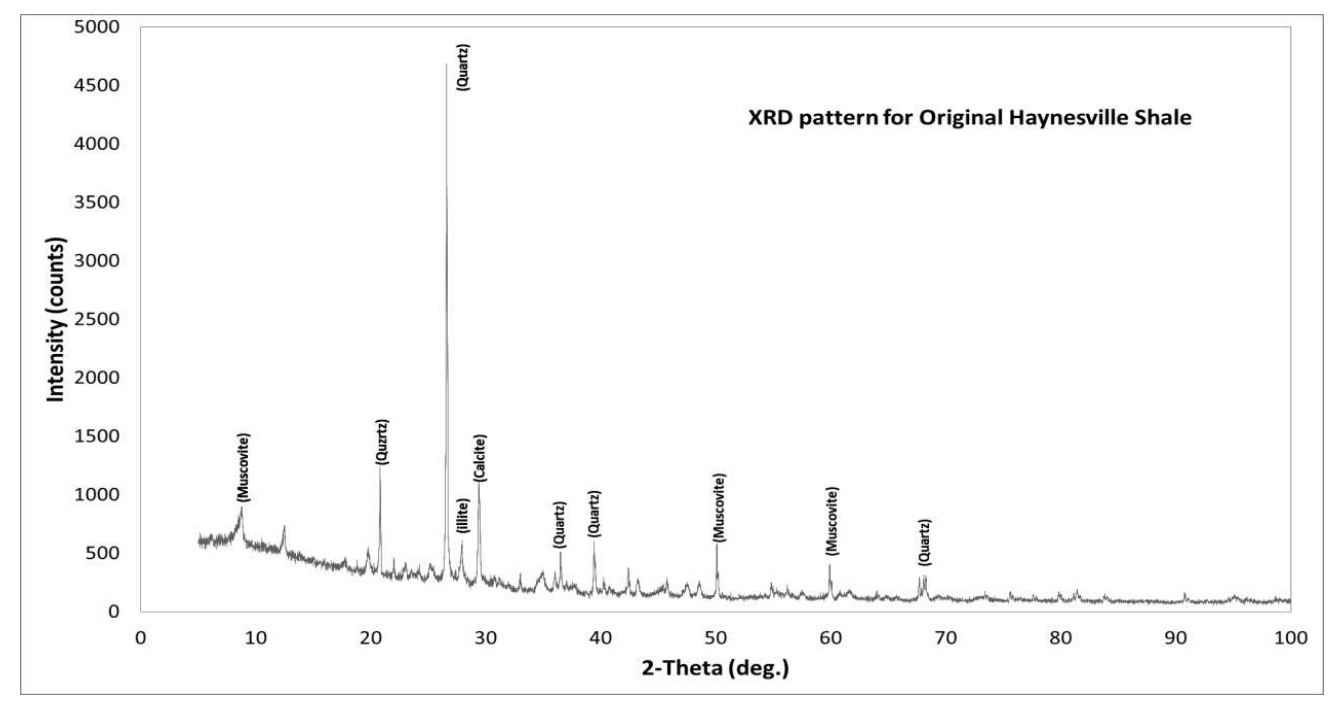

Figure 4. XRD pattern of original Haynesville shale 
Figure 4 shows that the average mineralogy of Hayesville shale was as follows: $24.1 \%$ Quartz, 43.2\% Illite, 0.9\% Kaolinite, 0.6\% Chlorite, 2.5\% Pyrite, 17.9\% Pyrite, and 3.0\% Dolomite. Although there are minor differences between the measured and the reported, the measured results are comparable to those reported $[42,43]$. Table 1 summarizes the results of all the shales used in this study.

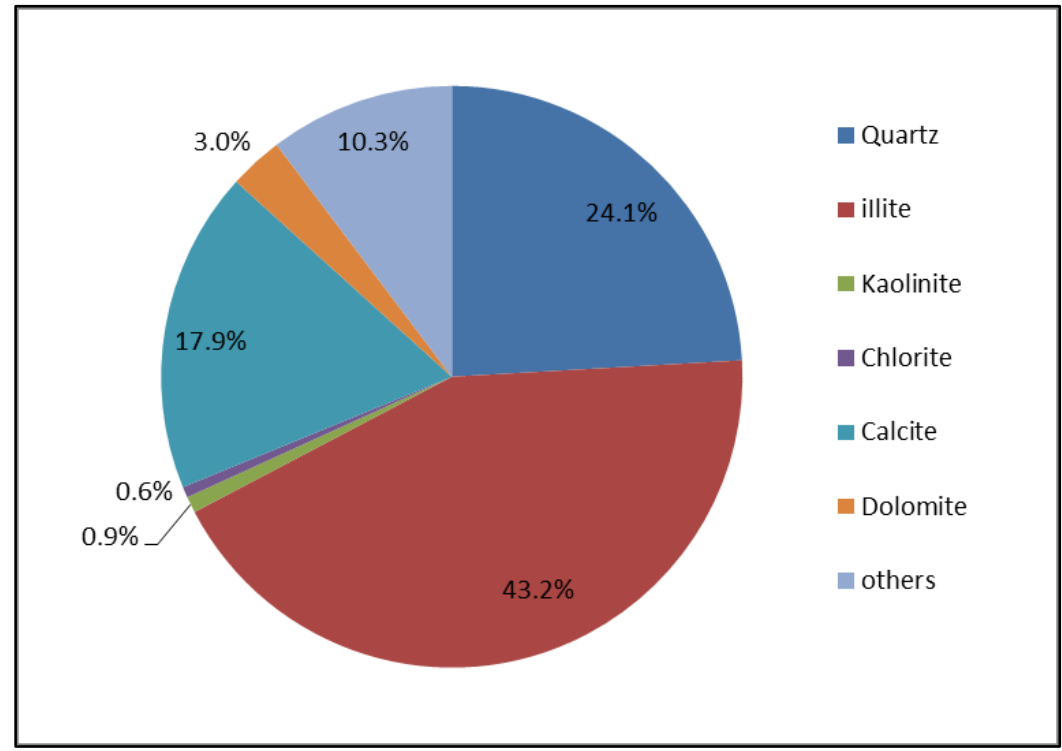

Figure 5. Mineralogy chart of Haynesville shale Table 1. Mineralogical Composition of Four Shales (\%)

\begin{tabular}{|c|c|c|c|c|c|c|c|c|c|}
\hline Shale & Quartz & illite & Kaolinite & Chlorite & $\begin{array}{c}\text { Total } \\
\text { clay }\end{array}$ & Calcite & Siderite & Dolomite & $\begin{array}{c}\text { Total } \\
\text { Carbonate }\end{array}$ \\
\hline Opalinus & 13.5 & 44.2 & 18.1 & 3.4 & 65.7 & 12.8 & 0.7 & 1.3 & 14.1 \\
Haynesville & 24.1 & 43.2 & 0.9 & 0.6 & 44.7 & 17.9 & 0 & 3.0 & 20.9 \\
\hline $\begin{array}{c}\text { Longmaxi } \\
\text { Eagle Ford }\end{array}$ & 26.3 & 35.6 & 0.8 & 0 & 36.4 & 2.0 & 0 & 10.3 & 12.3 \\
\hline
\end{tabular}

\subsection{Absorption-Desorption Curves}

The shape and hysteresis of low-temperature $\mathrm{N}_{2}$ adsorption-desorption isotherms can effectively characterize shale's pore morphology [44]. According to the International Union of Pure and Applied Chemistry (IUPAC) classification, isotherms can be divided into six types (I to VI), and their hysteresis modes can be designated Type A 
to Type D [45, 46, 47]. Figure 7(a) shows the $\mathrm{N}_{2}$ adsorption-desorption isotherms Haynesville shale before and after treatment. According to the IUPAC classification, the $\mathrm{N}_{2}$ adsorption isotherms and hysteresis modes of all tested shale samples can be classified as Type IV isotherms [48]. At a lower relative pressure $\left(\mathrm{P} / \mathrm{P}_{0}<0.01\right)$, the amount of adsorbed gas in all tested shale samples is low, while at a higher relative pressure $\left(\mathrm{P} / \mathrm{P}_{0}>0.9\right)$, the amount of adsorbed gas increases sharply. This phenomenon indicates that mainly micropores and mesopores with few large pores (larger than $50 \mathrm{~nm}$ ) contributing to the total porosity of samples. This hysteresis is mainly presenting in sequential Microporous and mesoporous materials in arranged, three-dimensional pore networks based on the IUPAC classifications. Figure 7(b) shows the isotherm comparison for Eagle Ford shale the pattern of Type III hysteresis. The Eagle Ford hysteresis loops are type C, demonstrating that in the Eagle Ford shales, slit-formed pores are the primary pores. Previous studies have shown the relation of plate-like pores to clay minerals $[49,50]$.
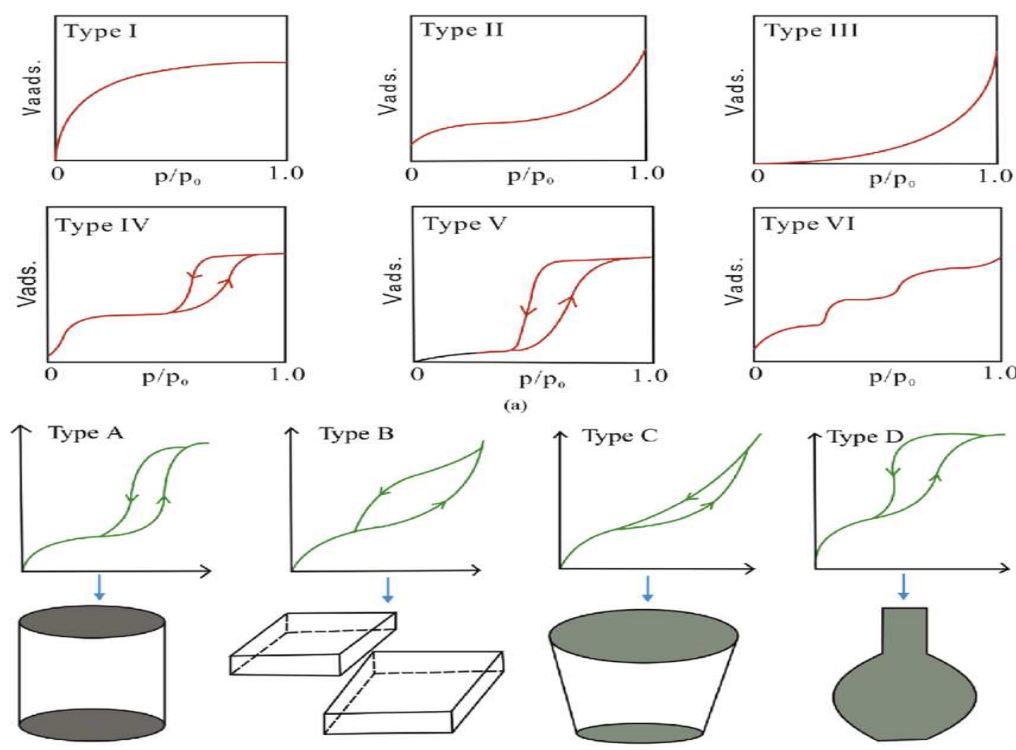

Figure 6. Adsorption isotherms types (a) and classification of hysteresis loops and their related pore shapes (b) $[51,52]$ 
The different compositions of clay minerals can cause variations in hysteresis loops types of Type III and Type IV [53]. The type D hysteresis loops of the remaining three shale samples indicate that the pore shape of these shale samples may be bottle-shaped pores (with narrow necks and large pore bodies) [54], as shown in Figures 6.

Figure 7 shows the Isotherm Comparison for four shales tested. For the Opalinus shale, the $\mathrm{N}_{2}$ adsorption capacity decreased from $0.0368 \mathrm{cc} / \mathrm{g}$ to $0.0346 \mathrm{cc} / \mathrm{g}$ by comparing the peak values from the isotherm graphs above, and the volumetric density was performed using the BET equation: both total volume and mass of the sample were treated to reflect the decrease in the $\mathrm{N}_{2}$ adsorption capacity of shale after treatment. Similarly, the maximum $\mathrm{N}_{2}$ adsorption capacity of Longmaxi, Eagle Ford, and Haynesville shales decreased from $0.0168 \mathrm{cc} / \mathrm{g}$ to $0.0148 \mathrm{cc} / \mathrm{g}, 0.04 \mathrm{cc} / \mathrm{g}$ to 0.032 $\mathrm{cc} / \mathrm{g}$, and $0.0177 \mathrm{cc} / \mathrm{g}$ to $0.0164 \mathrm{cc} / \mathrm{g}$, respectively, indicating that the $\mathrm{N}_{2}$ adsorption capacity of all shale samples has decreased after treatment. The adsorption capacity is mainly related to the number of micropores and mesopores. Therefore, the change in the $\mathrm{s}$ four shale samples' $\mathrm{N}_{2}$ adsorption capacity is attributed to the change in the pore structure.

\subsection{Pore Size Distribution of Original and Treated Shale}

Based on density functional theory (DFT) [55], the BET results can be converted to pore size distribution, as shown in Figures 8 . The pore size distributions in Figure 8 show subtle differences between the untreated and treated shale samples. However, the maximum amount of $\mathrm{N}_{2}$ adsorbed at the highest pressure changed. 


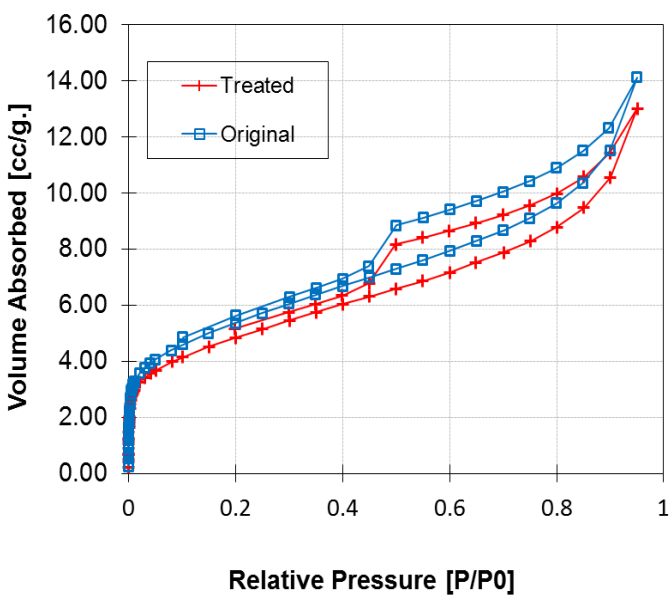

(a)

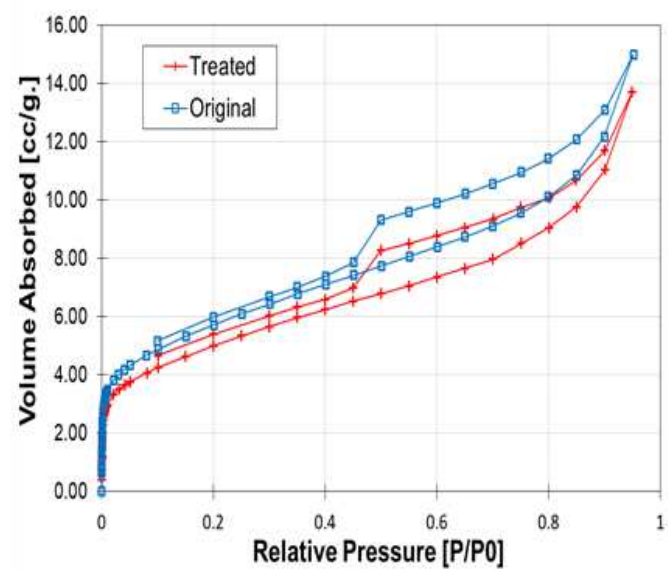

(c)

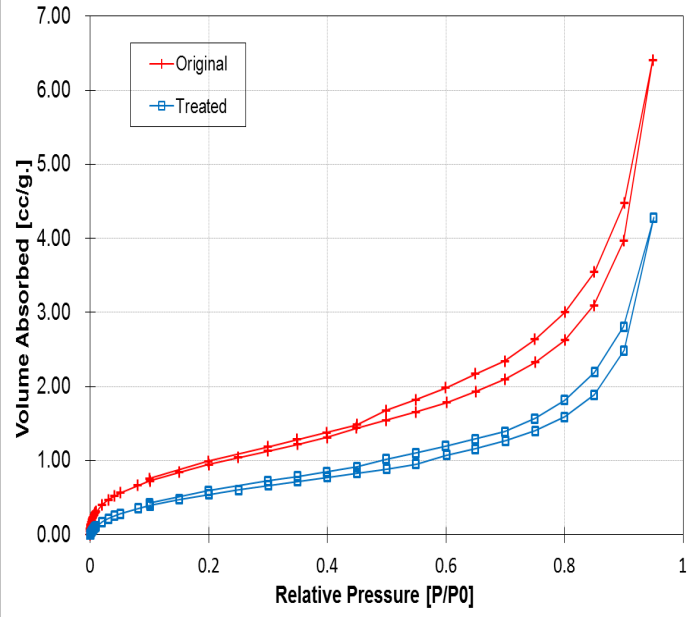

(b)

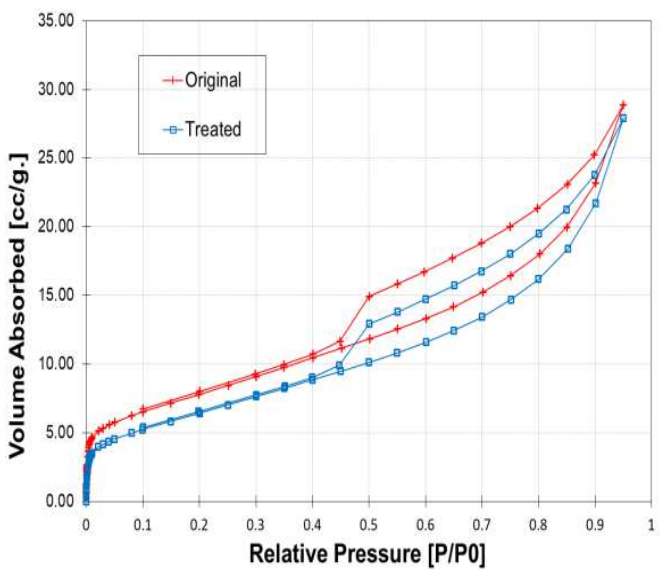

(d)

Figure 7. Isotherm Comparison for four shales tested (a) Haynesville, (b) Eagle Ford Shale, (c) Longmaxi Shale, and (d) Opalinus Shale The pore size distribution can be used to quantify the changes in the pore structure of shale samples. The pore size distributions of the four shales indicate that the shale pore structure is multimodal, where at least two significant peaks can be found in all pore sizes. The pore volumes of four shales were reduced from pore sizes in $1 \mathrm{~nm}$ to 5nm. However, after treatment, pore volumes of the Eagle Ford shale have significantly reduced from the untreated samples, indicating a massive change in micropores during treatment. Figure 8 shows that the peaks for the four shales are 
around $1 \mathrm{~nm}$ and $7 \mathrm{~nm}$ based on half pore width. The pore size distribution of the original four shales was altered after softening treatment.

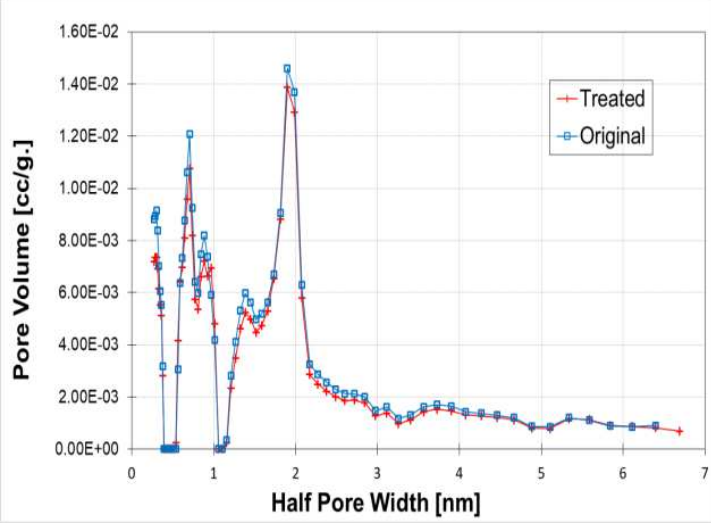

(a) Haynesville Shale

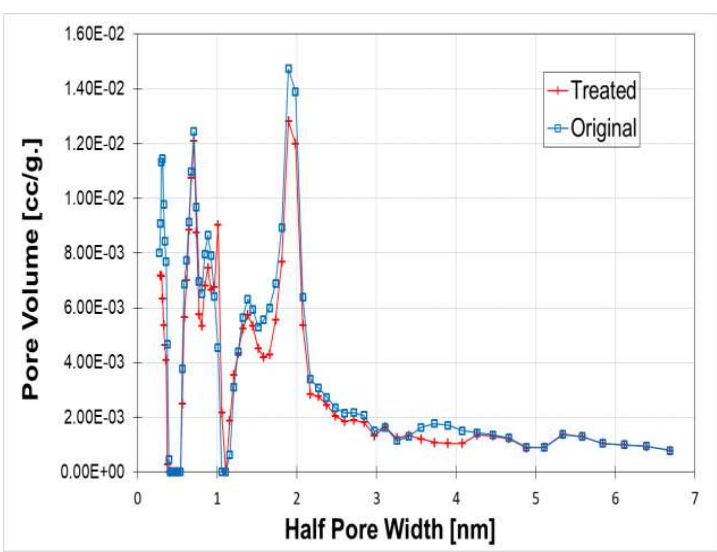

(c) Longmaxi Shale

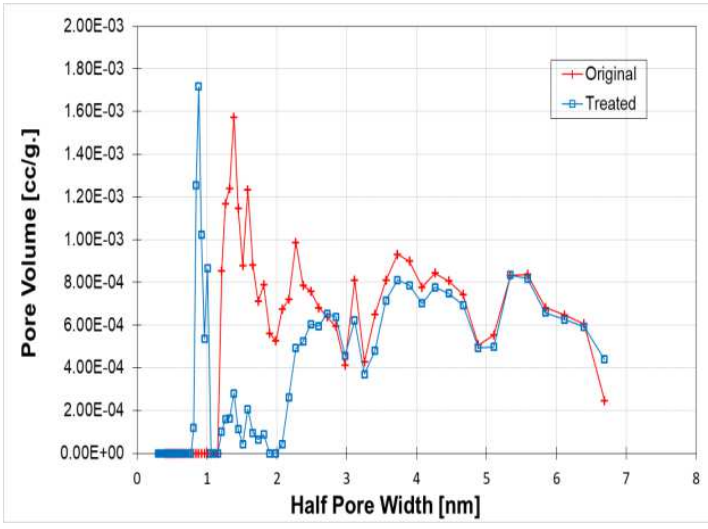

(b) Eagle Ford Shale

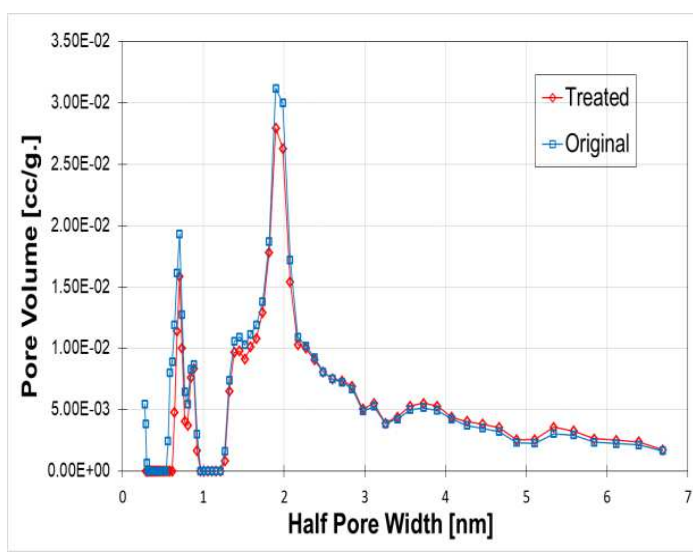

(d) Opalinus Shale

Figure 8. Pore size distribution comparison before and after treatment for four shales

(a) Haynesville, (b) Eagle Ford Shale, (c) Longmaxi Shale, and (d) Opalinus Shale

Figure 8(b) shows a significant change in peak volumes for Eagle Ford shale from $2 \mathrm{~nm}$ to $6 \mathrm{~nm}$. In this case, the large amount of inner Illite/Smectite (I/S) layer structure may contribute to a substantial change in pore sizes with clay swelling. Also, it was observed that after treatment from Figures $8(\mathrm{a})$, (c), and (d), the pore volumes of Haynesville, Longmaxi, and Opalinus shale have slightly reduced from pore sizes $0.7 \mathrm{~nm}$ to $2.1 \mathrm{~nm}$. 
After integration, the cumulative volume of the four shales was calculated and is reported in Table 2. Before each BET test, the dry weight of powder samples was measured using a highly sensitive scale. Hence, the porosity can be calculated knowing the density of each shale. The volumetric density of each original and treated shale were obtained from BET analysis, and powder mass was used to calculate porosity. It should be noted that the possible mass loss after the heating and degassing was neglected.

Table 2. Variation in Porosity between original and treated shale

\begin{tabular}{|c|c|c|c|c|}
\hline Sample & Volume/mass(Original) & $\begin{array}{c}\text { Volume/mass } \\
\text { (Treated) }\end{array}$ & Porosity(original) & $\begin{array}{c}\text { Porosity } \\
\text { (Treated) }\end{array}$ \\
\hline Longmaxi & $0.0177 \mathrm{cc} / \mathrm{g}$ & $0.0164 \mathrm{cc} / \mathrm{g}$ & $1.58 \%$ & $1.06 \%$ \\
Eagle Ford & $0.0168 \mathrm{cc} / \mathrm{g}$ & $0.0148 \mathrm{cc} / \mathrm{g}$ & $4.40 \%$ & $3.80 \%$ \\
Haynesville & $0.0401 \mathrm{cc} / \mathrm{g}$ & $0.0322 \mathrm{cc} / \mathrm{g}$ & $2.94 \%$ & $1.84 \%$ \\
\hline Opalinus & $0.0368 \mathrm{cc} / \mathrm{g}$ & $0.0346 \mathrm{cc} / \mathrm{g}$ & $7.80 \%$ & $3.80 \%$ \\
\hline
\end{tabular}

The distributions of the pore size are shown in Figure 8. Haynesville, Longmaxi, and Opalinus shale's pore size distributions indicate that the shale pore structure is multimodal. It is shown that these three shale peaks are around $2 \mathrm{~nm}$, while the Eagle Ford shale peaks were around $1 \mathrm{~nm}$. It was observed that the pore size distribution peak of Eagle Ford shale was shifted to $2 \mathrm{~nm}$ after water treatment indicating the pore structure was altered due to clay-water reaction. While Figure 8(a), (c), and (d) show no evidence of shifting of peaks, the I/S layer would be the primary reason for such peak changes. However, after the water-softening reaction, all shales' PSD decreased in pore volume at peaks lower than the initial samples. 
The clay content of tested shale varies from $65.7 \%$ (Opalinus shale) to $5.6 \%$ (Eagle Ford). The porosity comparison of four original and treated shale and the calculated loss in shale porosity were plotted with the total clay content shown in Figures 9. A linear correlation between clay content of four shales and porosity reduction rate after softening was obtained with the following relationship: $Y=0.6239 x+10.042, R^{2}=$ 0.9995 .

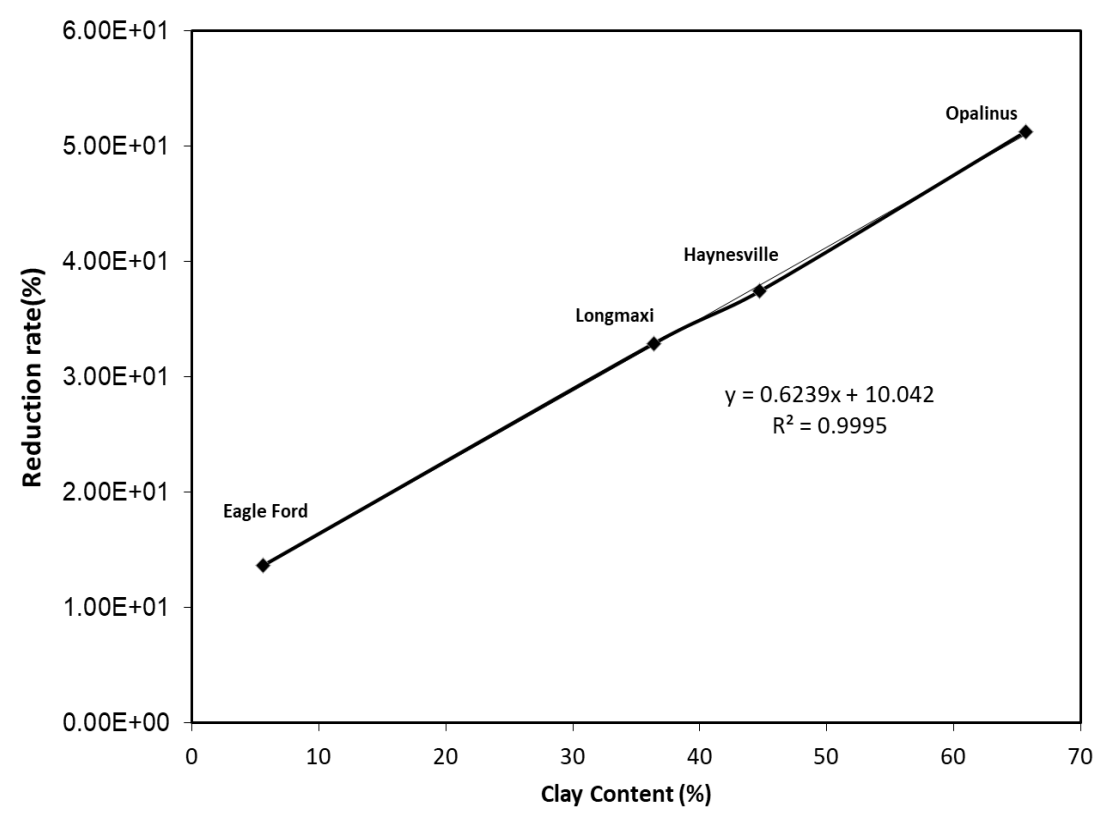

Figure 9. Correlation between clay content and porosity loss

\subsection{Discussion of Experimental Test Results}

After two series of four shale softening and treatment tests, several findings were found to describe the features of the clay-porosity correlations. The isothermal diagrams modification between initial and treatment can be inferred. Eagle Ford shale contains many I/S layers, contributing to a more swelling reduction of $1.1 \%$. Longmaxi, Haynesville, and Opalinus shale have the same isotherm pattern Type IV, and eagle ford shale may exhibit a pattern of Type III. PSD of these four shales was 
also carried out after treatment; peak changes can be used to calculate the porosity changes.

The clay minerals are essential components that can store oil and natural gas in the source and reservoir rocks. The presence of clay minerals can also strongly affect unconventional shale's physical and chemical properties [56]. Regionally, clay minerals can explain basin evolution, such as structure, sedimentation, burial and cementation history, etc. Also, clay minerals in gas-bearing rocks are an essential component to evaluate the quality of hydrocarbon generation, discharge, and migration. Their presence has an essential impact on reservoir properties (such as porosity and permeability). To determine the buried diagenesis process and to reveal pore types and pore evolution, geologists use clay mineral information. The clay content is generally considered to be detrimental to the quality of the reservoir because it can reduce or block pore throats sizes after hydraulic fracturing due to the retained injection fluid. During diagenesis, sediment porosity is substantially reduced for sediments with high clay contents but forms micro and nanopores and prevents cementation of quartz covered with chlorite. Therefore, it is natural to associate the reduction in porosity of gas-bearing shale with high clay contents after hydraulic fracturing [57]. When clay minerals become unstable and react with injection fluids to transform into more stable minerals, these will precipitate on the surface of the matrix particles and expand the rock skeleton [58]. These stable clay minerals can block pore passages, reduce the connectivity between the holes, and increase the flow resistance [59]. Water-based fracturing fluid can significantly reduce the porosity and 
permeability of the reservoir through the swelling of clay minerals. As demonstrated in this research, the pore throats of high clay content shale gradually swell or block under the influence of high temperature and pressure, reducing the shale gas production with time [60]. This transformation of hard rock into mudstone or soft shale is usually called shale softening.

\section{Impact of Shale Softening on Permeability}

Using a pore network and coupling the porosity change measured in this study will give insights into the permeability alteration and help understand the damage that the shale softening could bring. Based on spatial structures and porosity of original and treated shale, the permeability result will be compared in this chapter. Figure 10 shows a quarter of the $20 * 20 * 20$ network used in the simulation to illustrate the pore bodies connected to pore throats where pore bodies are spheres, and the pore throats are cylindrical. The pore bodies are connected by pore throats.

Based on several Longmaxi shale pore structure research [61, 62], the initial target shale of porosity $(1.58 \%)$ was reconstructed. Furthermore, reduced porosity will be achieved by reducing the pore body and pore throat with a swell ratio of 0.69 , as shown in Table 3.

Several assumptions were made for the simulation as follows:

- Assume that swelling initializes from the first layer of the grid in contact with hydraulic fracturing. 
- The pore body and the pore throat both swell due to clay-water reaction, but only the throat contributes to the matrix permeability (see the supplementary document for details).

- As the softening happens gradually, with the first layer swelling first and then continue to the next layer until the entire model is swelled.

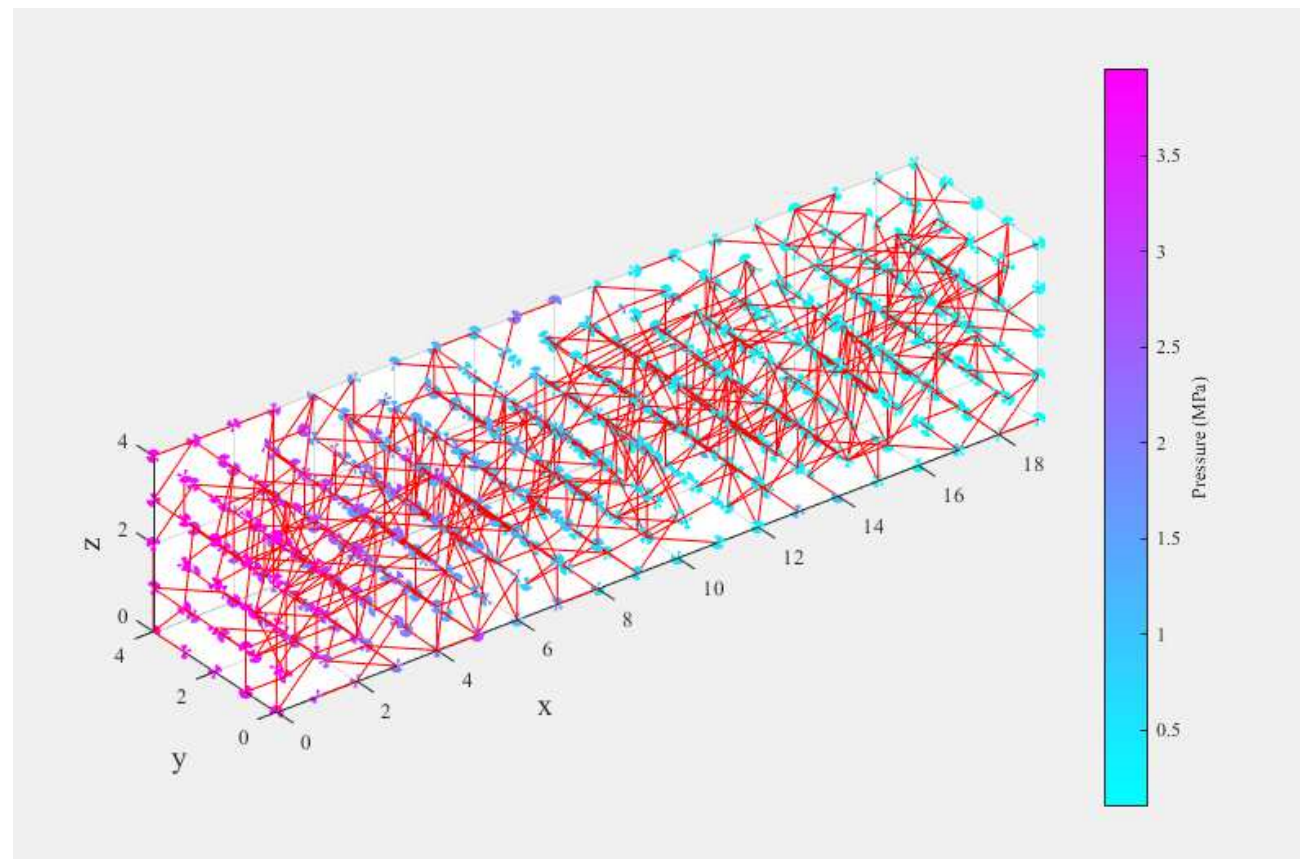

Figure 10. Illustration of a swelling pore network

Table 3. Original Longmaxi shale PNW parameters

\begin{tabular}{cccccc}
\hline Porosity & $\begin{array}{c}\text { Model } \\
\text { size }\end{array}$ & $\begin{array}{c}\text { Mean pore body } \\
\text { diameter(nm) }\end{array}$ & $\begin{array}{c}\text { Mean pore throat } \\
\text { diameter(nm) }\end{array}$ & $\begin{array}{c}\text { Coordination } \\
\text { number }\end{array}$ & $\begin{array}{c}\text { Swell } \\
\text { ratio }\end{array}$ \\
\hline $\begin{array}{c}\text { Original } \\
\mathbf{( 1 . 5 8 \% )}\end{array}$ & $20 * 20 * 20$ & 4.3 & 0.66 & 4 & 0 \\
$\begin{array}{c}\text { Treated } \\
\mathbf{( 1 . 0 6 \% )}\end{array}$ & $20 * 20 * 20$ & 2.9 & 0.45 & 4 & 0.69 \\
\hline
\end{tabular}

To demonstrate the swelling, Figure 11 shows an increase in swelling propagation through layers from no swell to swelling ratios of 0.35 and 0.69 for the layers in contact with hydraulic fracturing liquid, indicating swelling withthe progress of 
fracturing. The outlet pressure and inlet pressure are fixed at $100000 \mathrm{~Pa}$ and $200000 \mathrm{~Pa}$, respectively. The permeability of the original shale decreased dramatically as the swell ratio decreases. Figure 11 shows that the softening of shale is the main reason for the loss of permeability of the shale matrix.

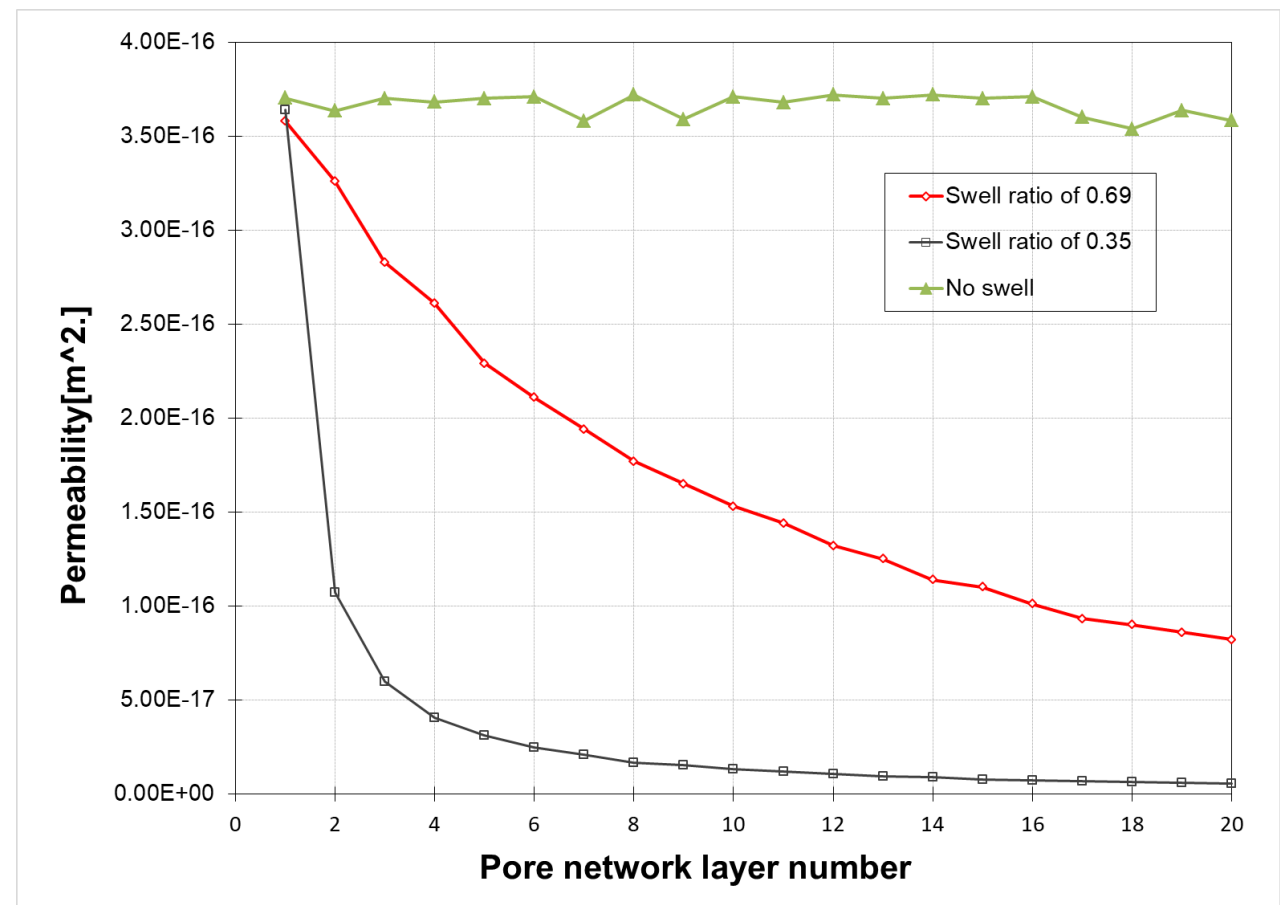

Figure 11. Impact of different swelling ratios on Permeability of Shale Matrix

It is reasonable to conclude that with the diffusion of moisture into the shale matrix, pore sizes in the whole grid decreases, and also the matrix permeability. In the extreme case, when all layers swell, the permeability matrix would be substantially smaller than the original permeability.

Four different simulations were performed to demonstrate further the stages of shale softening, which are situation 1(no swelling, original shale), situation 2(Layer one), situation 3(half of the layers), and situation 4(Treated shale), as shown in Fig 12. These stages represent hydraulic fracturing progress in which water seepage from the 
first layers to the entire grid. To understand the alteration of shale matrix permeability during fracturing for different stages, swell ratio and layer number were assigned.

This simulation outlet pressure was fixed at $0.1 \mathrm{MPa}$, and the inlet pressure was gradually increased from $0.1 \mathrm{MPa}$ to $4 \mathrm{MPa}$. The permeability decreases dramatically after half swelling to 0.39 of the initial permeability. In this case of Longmaxi shale, even though the porosity reduces only by $0.5 \%$ of the original shale, the permeability reduced to $21 \%$ of the original.

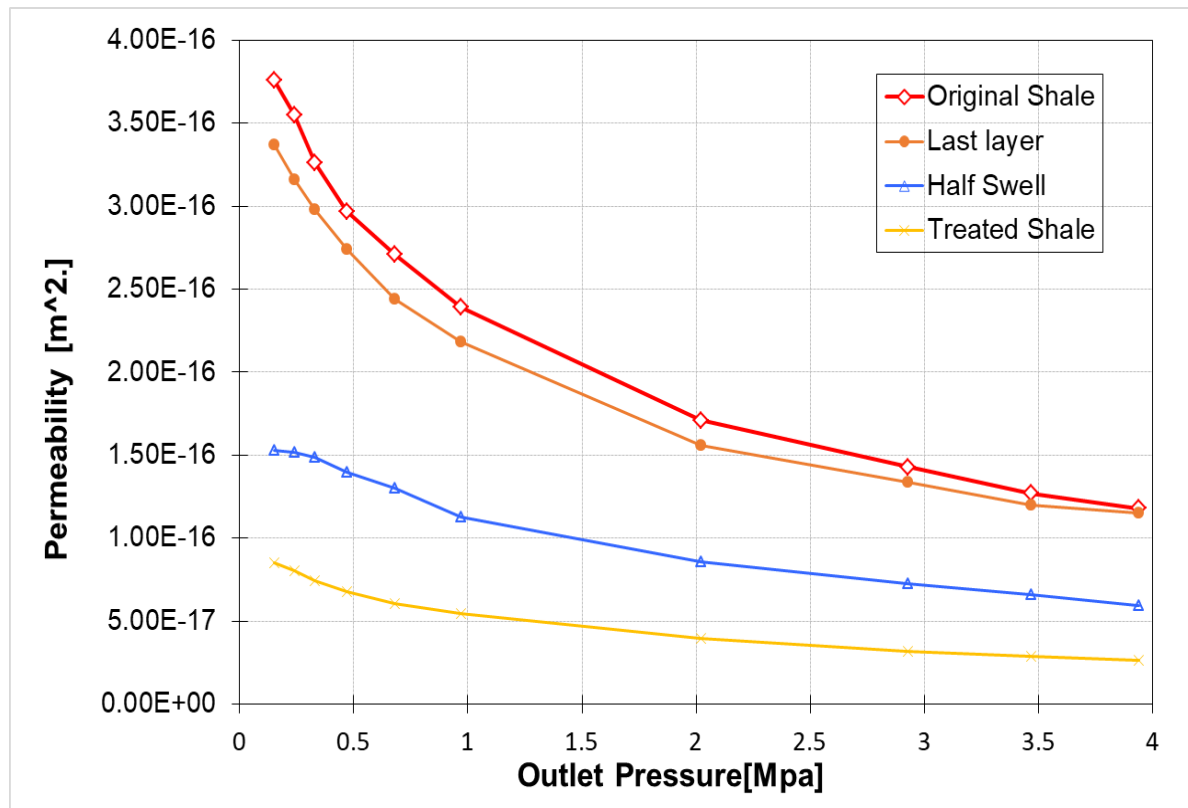

Figure 12. Permeability for different conditions of shale

Both swelling layers and swelling ratio are used to indicate the stage of shale softening. Permeability changes can be calculated using the swelling pore network model.

\section{Summary and Conclusions}

Four shale samples with different mineral compositions were used to study the influence of initial shale mineralogy on pore porosity evolution during hydraulic 
fracturing. Using XRD, low-temperature $\mathrm{N}_{2}$ adsorption, and porosity measurement methods, the changes in the mineral composition and pore structure characteristics of shale samples were measured. The conclusions of this study are summarized as follows:

(1) In the clay-rich Opalinus shale (clay content of $65.7 \%$ ), the clay softened after immersed in DI water at high temperature and pressure. The expansion of illite in Opalinus shale caused swelling of nanopores and led to a significant decrease in total pore volume (shale porosity decreased from $7.8 \%$ to $3.8 \%$ ).

(2) In the clay-poor Eagle Ford shale (clay content of 5.6\%), the clay is cemented with other non-water reaction minerals. The cementation of clay may occur at a slow rate, which the standard softening experiment cannot detect. However, the cementation of clay may block the majority of the pore throats. As a result, the porosity of the shale matrix is reduced from $1.06 \%$ to $0.52 \%$.

(3) The change in shale porosity with different mineral compositions during hydraulic fracturing may be related to the clay content of shale. Shales with low clay content have a low softening capacity, resulting in lower porosity loss during treatment. However, clay-rich shales have a high softening capacity. The test results show that during hydraulic fracturing, the initial mineral composition of the shale may affect the pore structure. Hence, the fracturing fluid should be adjusted according to the shale mineralogy to avoid damage to the intact shale.

(4) Preliminary results confirmed that shale softening has a negative impact on both the permeability of shale and gas production. Also, knowledge of shale's 
structural parameters can help identify shale softening stages, and simulation of shale softening provides a scientific way to predict the changes of permeability when given the structural parameters.

(5) A linear relationship between clay content and porosity reduction rate indicated that clay-rich shale would be water damaged the worst during hydraulic fracturing. Softening impacts the clay-rich shale the worst, as in this study: the Opalinus shale.

(6) Permeability tends to decrease with the propagation of swelling. The reduction of porosity will be the main reason for the drop in permeability. Even though the clay swelling-related porosity only decreases by $0.52 \%$, the permeability of treated shale is only 0.21 of the initial permeability.

\section{Acknowledgments}

The support of the Open Research Fund Program of State Key Laboratory of Hydroscience and Engineering (SKLHSE-2020-D-07) is acknowledged.

\section{References}

1. Bustin, R. M., "Geology Report: Where are the High-potential Reigns Expected to be in Canada and the U.S. Capturing Opportunities in Canadian Shale Gas," Second Annual Shale Gas Conference, the Canadian Institute, Calgary; Jan 31-Feb 1,2006

2. U.S. Energy Information Administration, "North America Leads the World in Production of Shale Gas," http://eia.gov (23 Oct. 2013)

3. Zeng, F., Guo, J., and Liu, L., and Xiao, Y., (2013), "Experience efficient 
fracturing of shale gas in North America and enlightenment to China," Southwest Petrol. Univ. Sci. Technol. Ed., 35 (6), pp. 90-98

4. Johnston, N., and Beeson, C. M., (1945), "Water permeability of reservoir sands," Am. Inst. Min. Eng., 160, pp. 43-55 SPE 945043

5. Morris, F. C., Aune, Q. A., and Gates, G. L., (1959), “Clay in Petroleum-Reservoir Rocks: Its Effects of Permeability, With Particular Reference to Tejon-Grapevine Area," U.S. Dept. of the Interior, Bureau of Mines, Kern County, CA, p. 5425

6. L.C. Goldenberg, S. Mandel, M. Magaritz (1986) Fluctuating, nonhomogeneous changes of hydraulic conductivity in porous medium Q. J. Eng. Geol. Hydrol., 19, pp. $183-190$

7. Fink, D. H., Rich, C. I. and Thomas, G. W., (1968), "Determination of internal surface area, external water and amount of montmorillonite in clay-water systems," Soil Sci., 105, pp. 71-77

8. Mohan, K. K., Marion, G., and Fogler, H. S., (1998), "Formation damage in smectitic sandstones by high ionic strength brines," J. Colloid Surf., 154, pp. $249-257$

9. Norrish, K., (1954), “The swelling of montmorillonite," Faraday Soc., 18, pp. $121-134$

10. Zhang, Z. Z., and Low, P. F., (1989), "Relation between the heat of immersion and the initial water content of Li-, Na- and K montmorillonite," J. Colloid Interface Sci., 133, pp. 461-472

11. Wilson, L., Wilson, M. J., Greena, J., and Pateya, I., (2014), "The influence of 
clay mineralogy on formation damage in North Sea reservoir sandstones: A review with illustrative examples,” Earth Sci. Rev., 134, pp. 70-80

12. Davy, C. A., Skoczylas, F., Barnichon, J.D., and Lebon, P., (2007), "Permeability of macro-crackedargillite under confinement: gas and water testing," Phys. Chem. Earth, 32, pp. 667-680

13. Matmon, D., and Hayden, N. J., (2003), "Pore space analysis of NAPL distribution in sand-clay media," Adv. Water Resources., 26, pp. 773-785

14. Barnaji, M. J., Pourafshary, P., and Rasaie, M. R., (2016), "Visual investigation of the effects of clay minerals on the enhancement of oil recovery by low salinity water flooding," Fuel, 184, pp. 826-835

15. Goldenberg, L. C., Mandel, S., and Magaritz, M., (1986), "Fluctuating, Nonhomogeneous changes of hydraulic conductivity in porous medium," Q. J. Eng. Geol. Hydrol., 19, pp. 183-190

16. Du, J., Hu, L., Meegoda, J. N., and Zhang, G. (2018), "Shale softening: Observations, phenomenological behavior, and mechanisms," Applied Clay Science, 161, 290-300.

17. Du, J., Whittle, A. J., Hu, L., Divoux, T., and Meegoda, J. N., (2021), "Characterization of Meso-Scale Mechanical Properties of Longmaxi Shale Using Grid-Micro-indentation Experiments," Journal of Rock Mechanics and Geotechnical Engineering, https://doi.org/10.1016/j.jrmge.2020.09.009, V13 \#3, June 2021

18. Wu, W., and Sharma, M. M. (2017), "Acid fracturing in shales: effect of dilute 
acid on properties and pore structure of shale," SPE Production \& Operations, 32(01), 51-63.

19. Sun, Z., Zhang, H., Wei, Z., Wang, Y., Wu, B., Zhuo, S., Zhao, Z., Li, J., Hao, L. and Yang, H., (2018), "Effects of slickwater fracturing fluid on pore structure and adsorption characteristics of shale reservoir rocks," Journal of Natural Gas Science and Engineering, 51, 27-36.

20. Baars, C., and Horak, J., (2018), "Storage and conservation of geological collections-A research agenda,” J. Inst. Conserv., 41, 154-168

21. Gasc-Barbier, M., and Tessier, D., (2007), "Structural modifications of a hard deep clayey rock due to hygro-mechanical solicitations,” Int. J. Geomech., 7, 227-235

22. Ferrari, A., Favero, V., Marschall, P., and Laloui, L., (2014), "Experimental analysis of the water retention behavior of shales," Int. J. Rock, Mech. Min. Sci., $72,61-70$.

23. Ewy, R.T., (2015), "Shale/Claystone response to air and liquid exposure, and implications for handling, sampling, and testing,” Int. J. Rock, Mech. Min. Sci., $80,388-401$.

24. Sridharan, A, Rao, S. M., and Sashi, S., (1990), "Classification of expansive soils by sediment volume method," Geotech Test J 13(4):375-380

25. Yilmaz, I., (2006), "Indirect estimation of the swelling percent and a new classification of soils depending on liquid limit and cation exchange capacity," Eng. Geology 85(3-4):295-301

26. Lee, J. M., Shackelford, C. D., Benson, C. H., Jo. H. Y., Edil, T. B. (2005), 
"Correlating index properties and hydraulic conductivity of geosynthetic clay liners," J Geotech and Geo-environmental Eng 131(11):1319-1329

27. Mishra, A. K., Ohtsubo, M., Li, L., Higashi, T. (2005), "Effect of salt concentrations on the permeability and compressibility of soil-bentonite mixtures," J Fac Agric Kyushu Univ 50(2):837-849.

28. Alawaji, H. A., (1999), "Swell and compressibility characteristics of sandbentonite mixtures inundated with liquids," Appl Clay Sci 15:411-430

29. Fink, D. H., Rich, C. I., and Thomas, G. W., (1968), “Determination of internal surface area, external water and amount of montmorillonite in clay-water systems," Soil Sci., 105, pp. 71-77

30. Meegoda, J. N. and Martin, L., (2019) "In-Situ Specific Surface Area of Clays," Geotechnical and Geological Engineering, https://doi.org/10.1007/s10706-018-0623-7

31. Zolfaghari, A., Dehghanpour, H., Noel, M., and Bearinger, D., (2016), "Laboratory and field analysis of flow-back water from gas shales," J. Union. Oil Gas Resour, 14, 113- 127

32. Ali, M., and Hascakir, B., (2017), "Water/Rock Interaction for Eagle Ford, Marcellus, Green River, and Barnett Shale Samples and Implications for Hydraulic-Fracturing," Fluid Engineering. 22 (01), 162- 171

33. Gutierrez, M. A., Elston, H., and Cole, D., (2014), "Petrophysical Analysis of Eagle Ford Shale: A Preliminary Assessment," Presented at the AAPG Eastern Section, 43rd Annual Meeting, London, Ontario, Canada. 
34. Franklin, J., Vogler, U., Szlavin, J., Edmond, J., and Bieniawski, Z., (1981), "Suggested methods for determining water content, porosity, density, absorption, and related properties and swelling and slake-durability index properties," In E. Brown (Ed.), Rock Characterization Testing and Monitoring, ISRM Suggested Methods (pp. 79-94). Oxford: Pergamon Press.

35. Zhang, P., Hu, L., Meegoda, J. N. and Gao, S., (2015), "Micro/Nano-pore Network Analysis of Gas Flow in Shale Matrix," Sci Rep 5, 13501, doi:10.1038/srep13501 (2015).

36. Gao, S., Meegoda, J. N., and Hu, L., (2012), “Two methods for pore network of porous media," IJNAM 36, 1954-1970, doi: https://doi.org/10.1002/nag.1134.

37. Zhang, P., Hu, L., and Meegoda, J. N., (2017), "Pore-Scale Simulation and Sensitivity Analysis of Apparent Gas Permeability in Shale Matrix," Materials (Basel) 10, doi:10.3390/ma10020104.

38. Friedman, G., (2003), "Classification of sedimentary rocks,” In G. V. Middleton (Ed.), Encyclopedia of Sediments and sedimentary rocks Kluwer Academic encyclopedia of earth sciences series. Dordrecht, The Netherlands; Boston: Kluwer Academic Publishers.

39. Groen, J. C., Peffer, L. A. A., and Pérez-Ramírez, J. (2003), "Pore size determination in modified micro-and mesoporous materials, Pitfalls and limitations in gas adsorption data analysis," Microporous and Mesoporous Materials, 60, 1-17.

40. Chipera, S. J., and Bish, D. L., (2013), "Fitting full x-ray diffraction patterns for 
quantitative analysis: a method for readily quantifying crystalline and disordered phases," Adv. Mater. Phys. Chem., 03, pp. 47-53

41. Seiphoori, A., Moradian, Z., Einstein, H., and Whittle, A., (2016). Microstructural characterization of Opalinus shale, Paper presented at the 50th U.S. Rock Mechanics/Geomechanics Symposium, Houston, Texas, Paper Number: ARMA-2016-783.

42. Sun, S., Feng, L., Tang, L., Wu, J., and Ma, C., (2017), "Microstructural investigation of gas shale in Longmaxi Formation, Lower Silurian, NE Sichuan Basin, China," Energy Exploration and Exploitation. 35. 406-429. $10.1177 / 0144598716684304$.

43. SWPU, (2017), "Mechanism of polymer adsorption on shale surfaces: Effect of polymer type and presence of monovalent and divalent salts," Petroleum. 3. 384-390.

44. Kuila, U., and Prasad, M. (2013), "Specific surface area and pore-size distribution in clays and shales," Geophysical Prospecting, 61 (Rock Physics for Reservoir Exploration, Characterization and Monitoring), 341-362.

45. Li, Y., Wang, Z., Pan, Z., Niu, X., Yu, Y., and Meng, S. (2019), "Pore structure and its fractal dimensions of transitional shale: A cross-section from east margin of the Ordos Basin, China,” Fuel, 241, 417-431.

46. Hu, J., Tang, S., and Zhang, S., (2016), "Investigation of pore structure and fractal characteristics of the Lower Silurian Longmaxi shales in western Hunan and Hubei Provinces in China," Journal of Natural Gas Science and Engineering, 28, 
$522-535$.

47. Gou, Q., Xu, S., Hao, F., Yang, F., Zhang, B., Shu, Z., and Qing, J., (2019), "Full-scale pores and micro-fractures characterization using FE-SEM, gas adsorption, nano-CT and micro-CT: A case study of the Silurian Longmaxi Formation shale in the Fuling area, Sichuan Basin, China," Fuel, 253, 167-179.

48. Harrison, A. L., Jew, A. D., and Dustin, M. K., (2017), "Element release and reaction-induced porosity alteration during shale-hydraulic fracturing fluid interactions," Applied Geochemistry, vol. 82, pp. 47-62.

49. Ji, L., Zhang, T., Milliken, K., Qu, J., and Zhang, X., (2012), "Experimental investigation of main controls to methane adsorption in clay-rich rocks," Appl. Geochem., 27, 2533-2545.

50. Milliken, K.L., and Reed, R. M., (2010), "Multiple causes of diagenetic fabric anisotropy in weakly consolidated mud, Nankai accretionary prism," IODP Expedition 316. J. Struct. Geol., 32, 1887-1898.

51. Donohue, M., and Aranovich, G. L., (1998), "Classification of Gibbs adsorption isotherms," Advances in Colloid and Interface Science. 76. 137-152. 10.1016/S0001-8686(98)00044-X.

52. Labani, M. M., Rezaee, R., Saeedi, A., Hinai, A. A., (2013), "Evaluation of pore size spectrum of gas shale reservoirs using low pressure nitrogen adsorption, gas expansion and mercury porosimetry: A case study from the Perth and Canning Basins, Western Australia," Journal of Petroleum Science and Engineering, Volume 112, Pages 7-16, 
53. Kuila, U., McCarty, D. K., Derkowski, A., Fischer, T. B., Topór, T., Prasad, M., (2014), "Nano-scale texture and porosity of organic matter and clay minerals in organic-rich mudrocks," Fuel, 135, 359-373.

54. Yang, C., Zhang, J., Han, S., Wang, X., Wang, L., Yu, W., Wang, Z., (2016), "Compositional controls on pore-size distribution by nitrogen adsorption technique in the Lower Permian Shanxi Shales, Ordos Basin,” J. Nat. Gas Sci. Eng., 34, 1369-1381.

55. Wang, R., Zhang, N., Liu, X., Wu, X., Chen, J., and Ma, L., (2015), "Characteristics of pore volume distribution and methane adsorption on shales", Adsorption Science \& Technology, 33(10), 915-937.

56. Morrow, C. P., Yazaydin, A. Ö., Krishnan, M., Bowers, G. M., Kalinichev, A. G., and Kirkpatrick, R. J., (2013), "Structure, Energetics, and Dynamics of Smectite Clay Interlayer Hydration: Molecular Dynamics and Metadynamics Investigation of Na-Hectorite,” J. Phys. Chem. C, 117 (10), 5172- 5187,

57. Kowalczyk, P., Terzyk, A. P., Gauden, P. A., Leboda, R., Szmechtig-Gauden, E., Rychlicki, G., and Rong, H., (2003), "Estimation of the pore-size distribution function from the nitrogen adsorption isotherm. Comparison of density functional theory and the method of Do and co-workers," Carbon, 41(6), 1113-1125.

58. Anovitz, L. M., and Cole, D. R., (2015), "Characterization and analysis of porosity and pore structures," Reviews in Mineralogy and geochemistry, 80(1), 61-164.

59. Dehghanpour, H., Lan, Q., Saeed, Y., Fei, H., and Qi, Z., (2013), “Spontaneous 
Imbibition of Brine and Oil in Gas Shales: Effect of Water Adsorption and Resulting Microfractures,” Energy Fuels, 27 (6), 3039- 3049

60. Vengosh, A., Jackson, R. B., Warner, N., Darrah, T. H., and Kondash, A., (2014), "A Critical Review of the Risks to Water Resources from Unconventional Shale Gas Development and Hydraulic Fracturing in the United States," Environ. Sci. Technol., 48 (15), 8334- 8348

61. Gao, J., Xia, L., Li, Y. and Yu, Q., (2016), "Percolation characteristics of Carboniferous shale gas in Eastern Qaidam Basin.” Earth Science Frontiers 23, 103-112.

62. Zhang, D., Zhang, X., Guo, H., Lin, D., Meegoda, J. N., and Hu, L., (2021), “An Anisotropic Pore-network Model to Estimate the Shale Gas Permeability," Scientific Reports, https://doi.org/10.1038/s41598-021-86829-4 
Figures

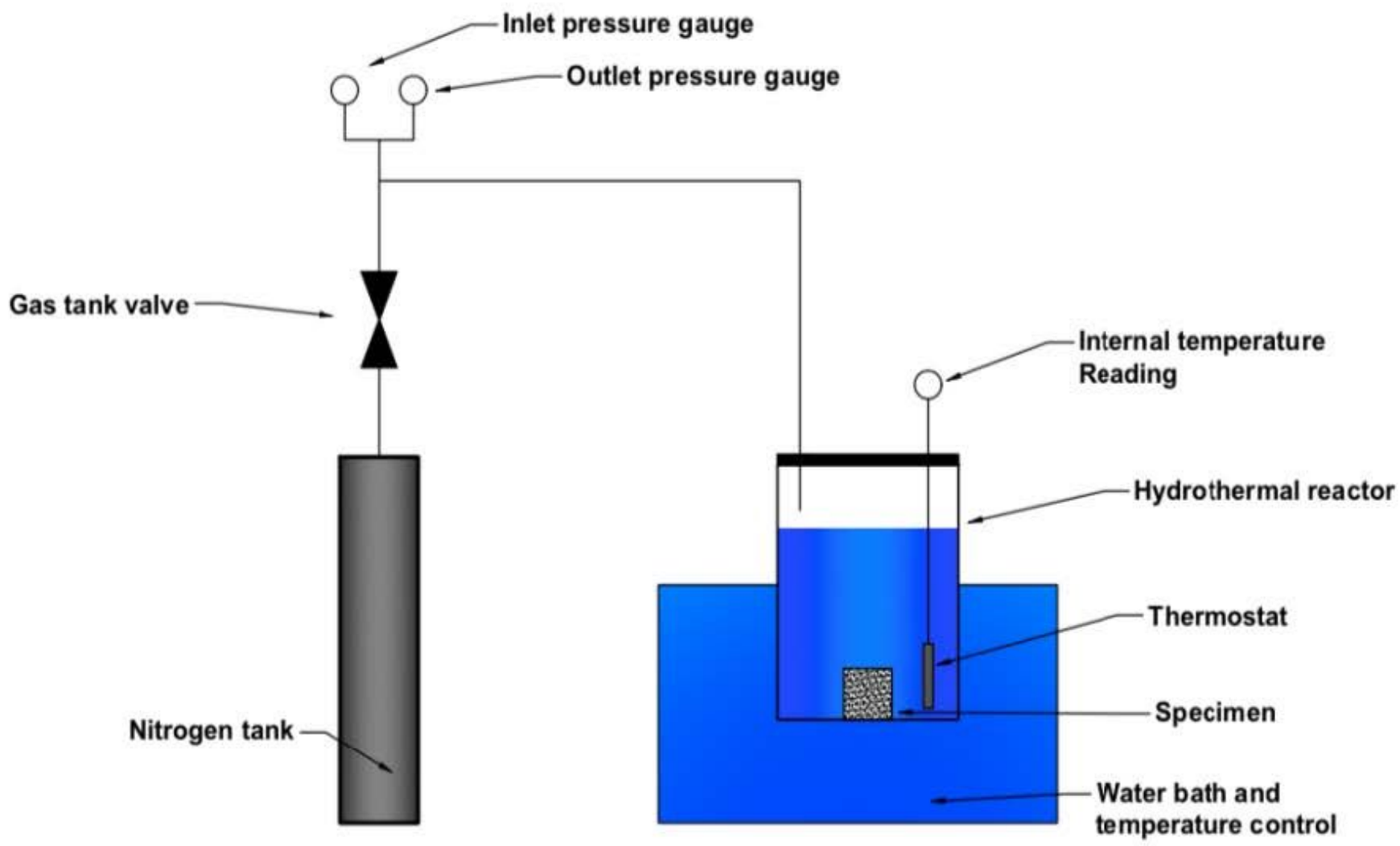

Figure 1

Shale Treatment Setup

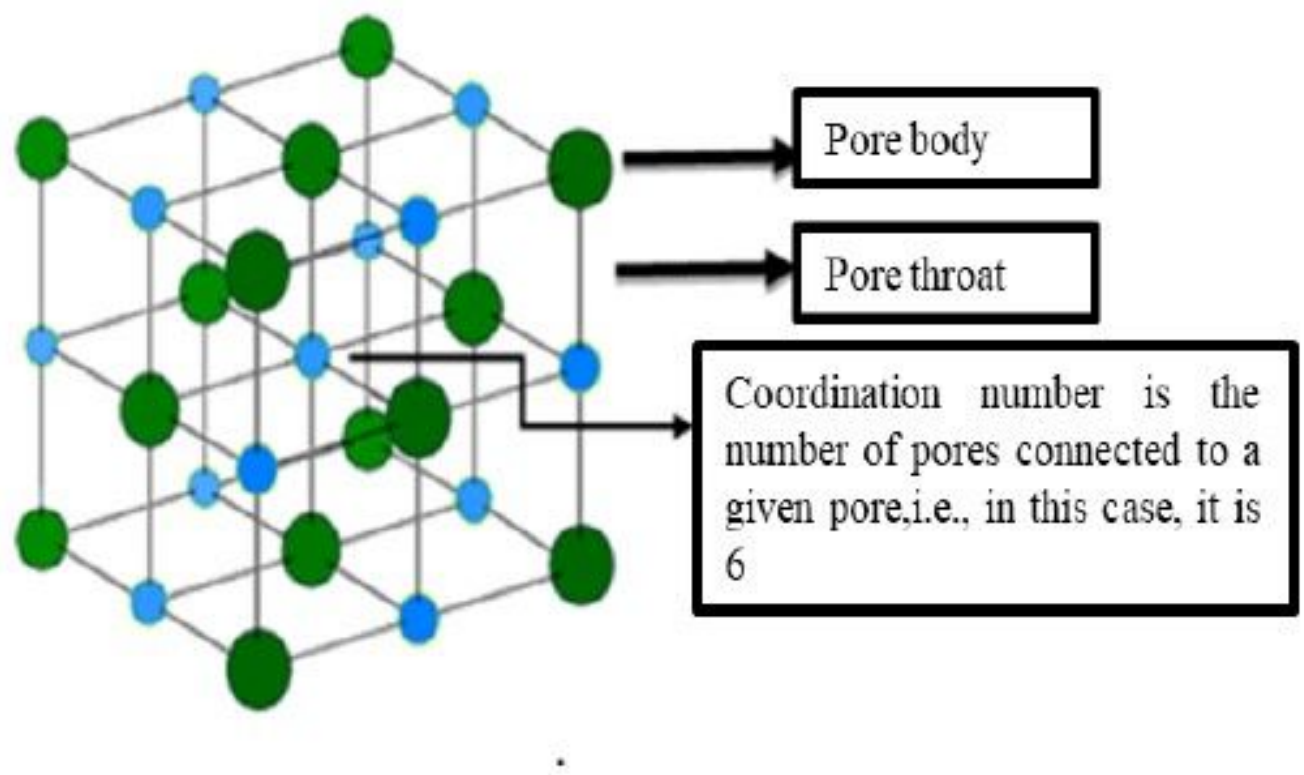

Figure 2 
Schematic of each component

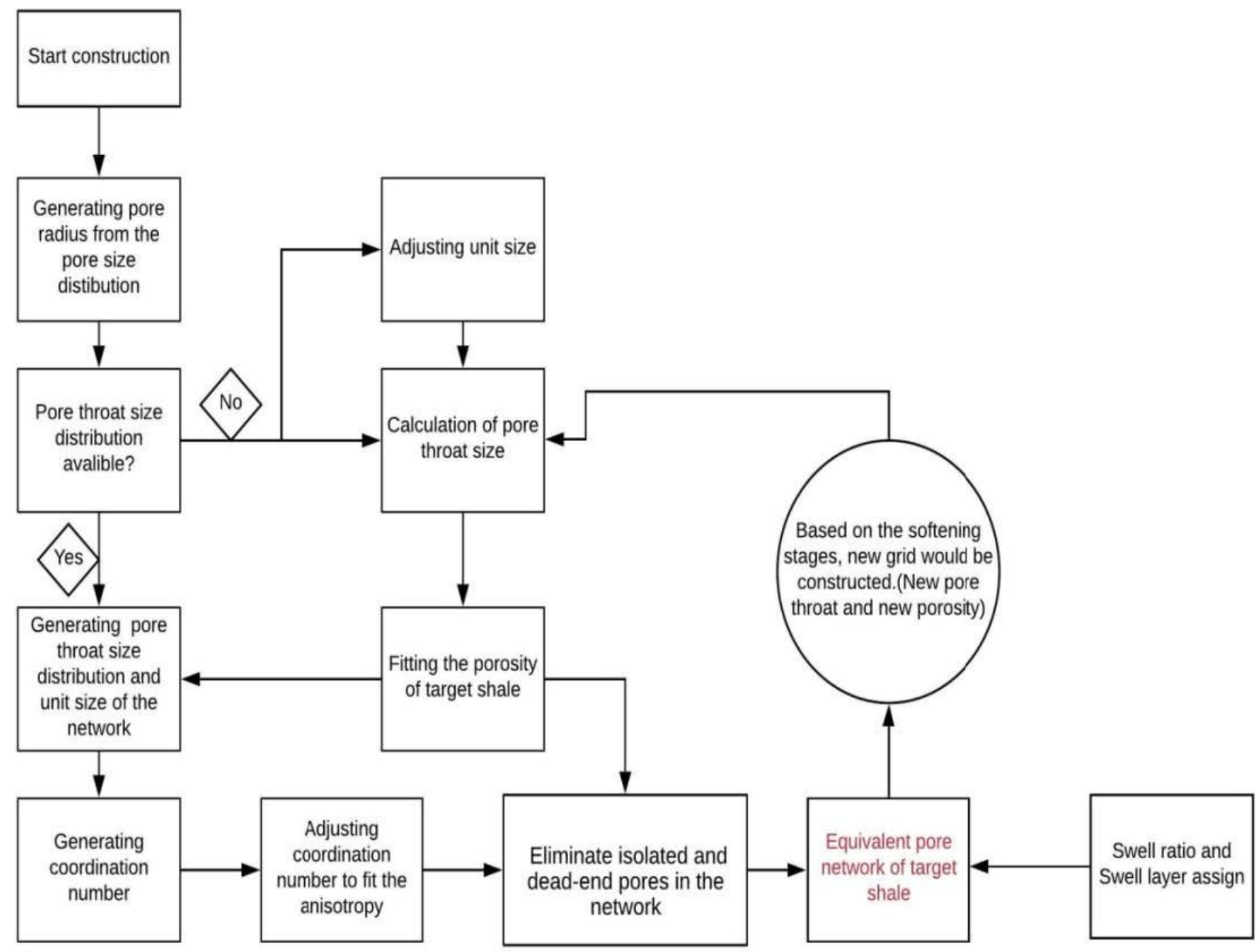

Figure 3

Flowchart of constructing swelling pore network model 


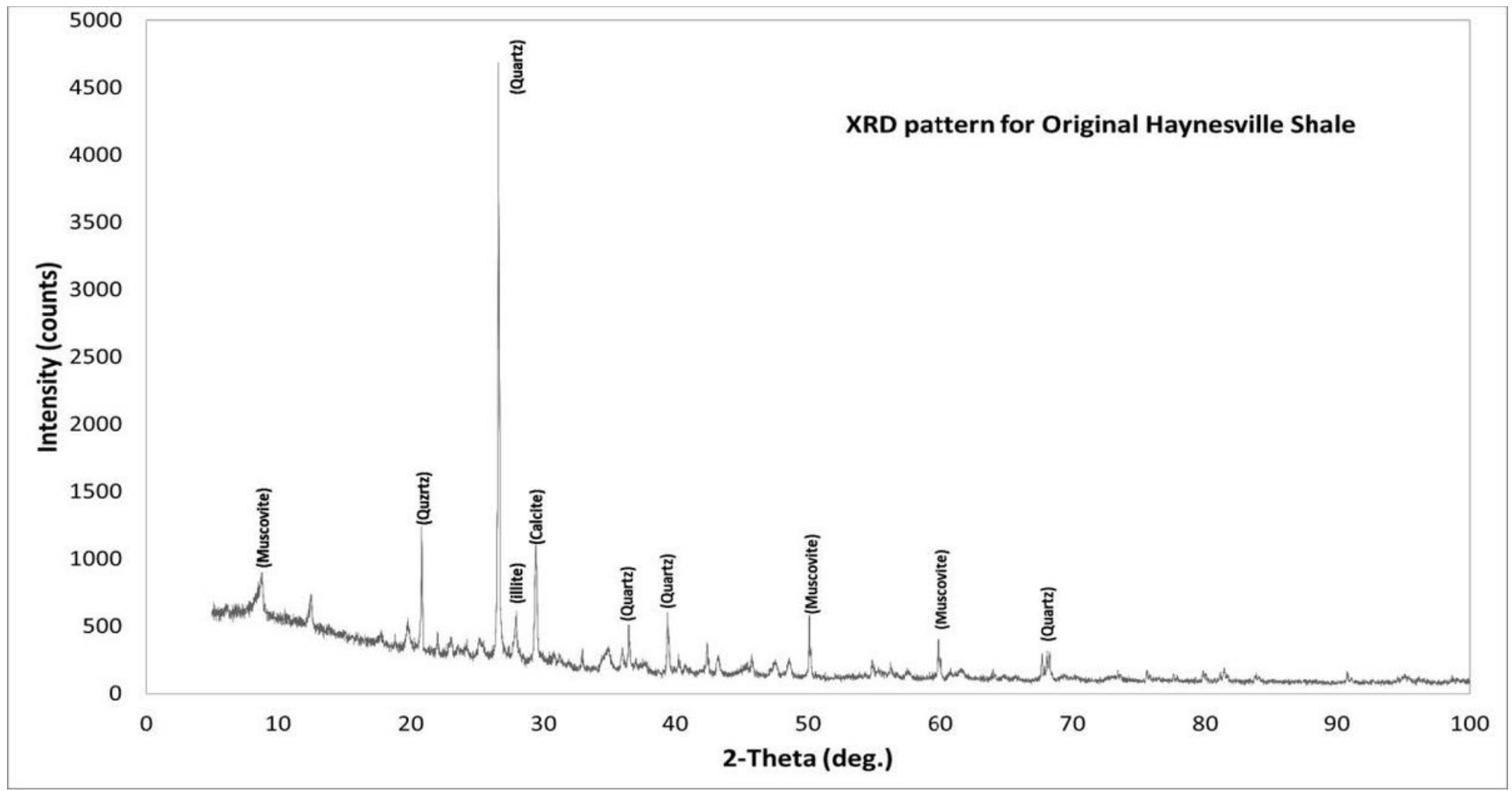

Figure 4

XRD pattern of original Haynesville shale 


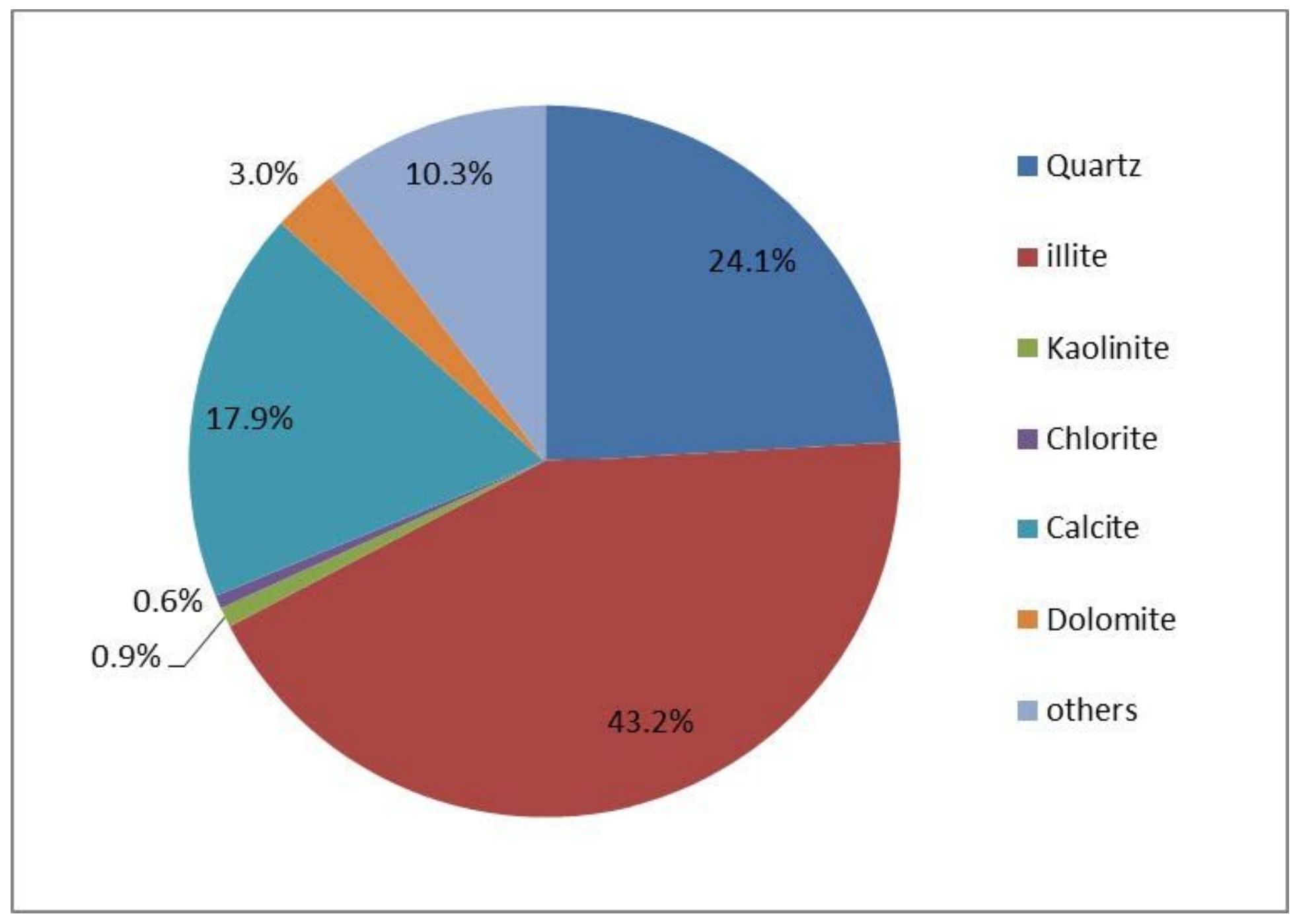

Figure 5

Mineralogy chart of Haynesville shale 

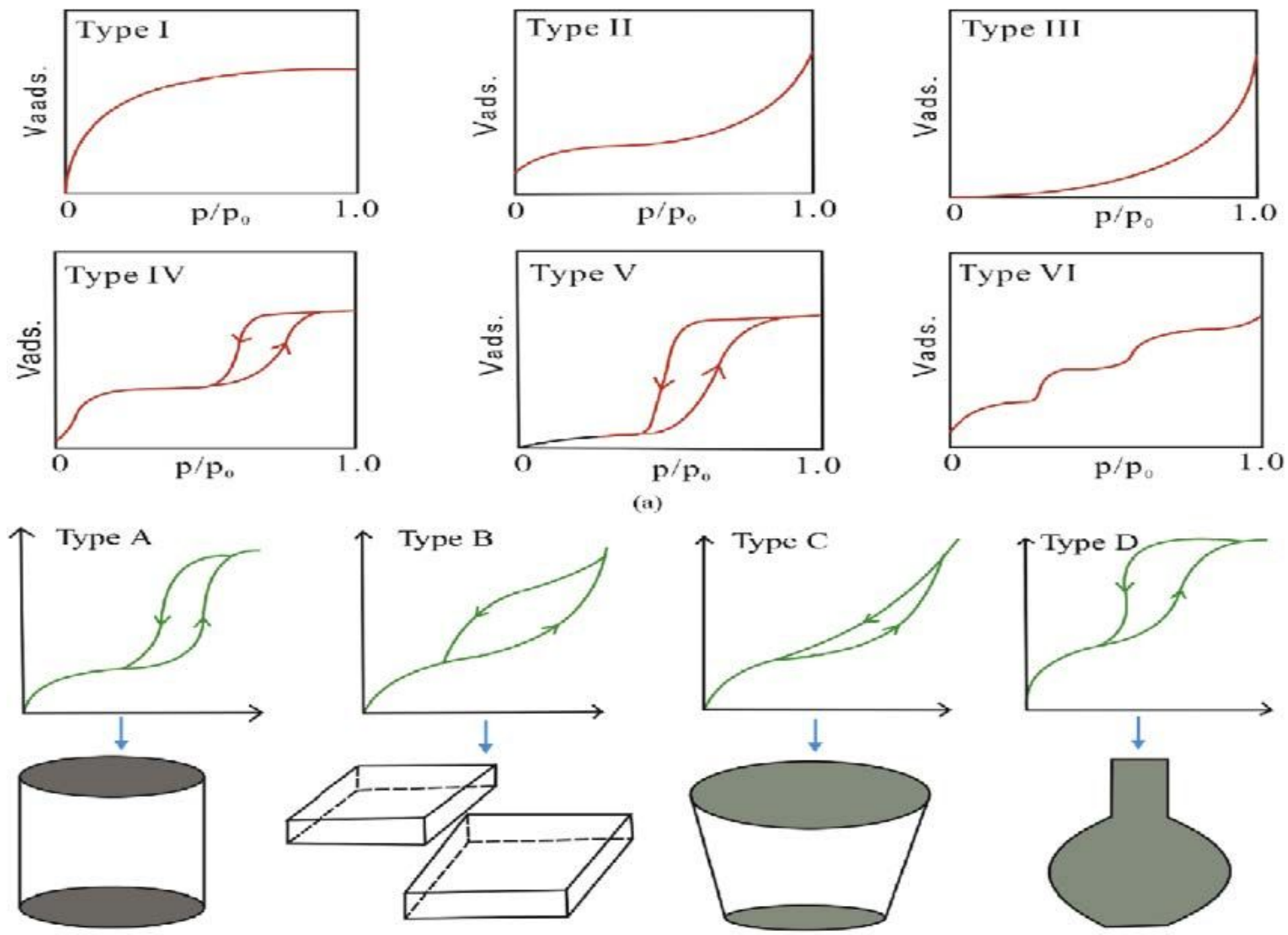

(b)

Figure 6

Adsorption isotherms types (a) and classification of hysteresis loops and their related pore shapes (b) $[51,52]$ 


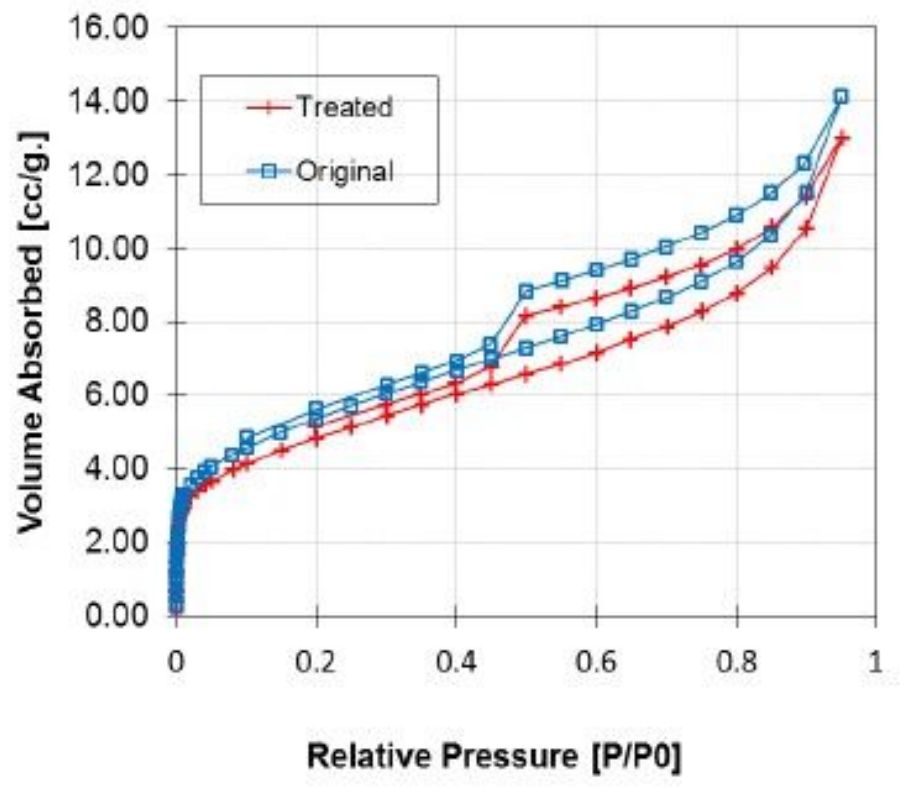

(a)

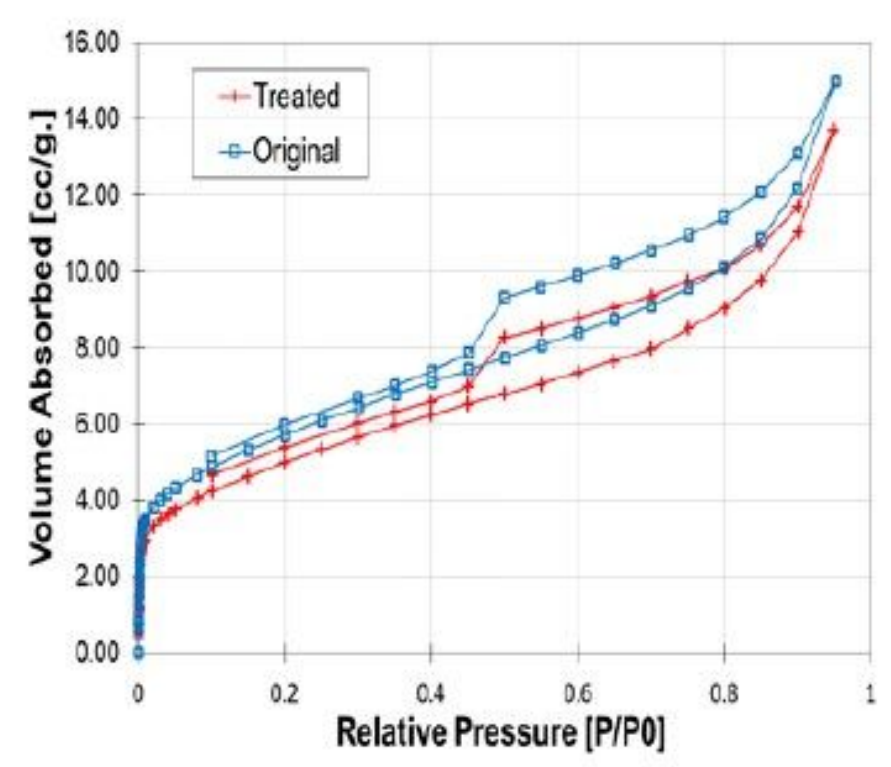

(c)

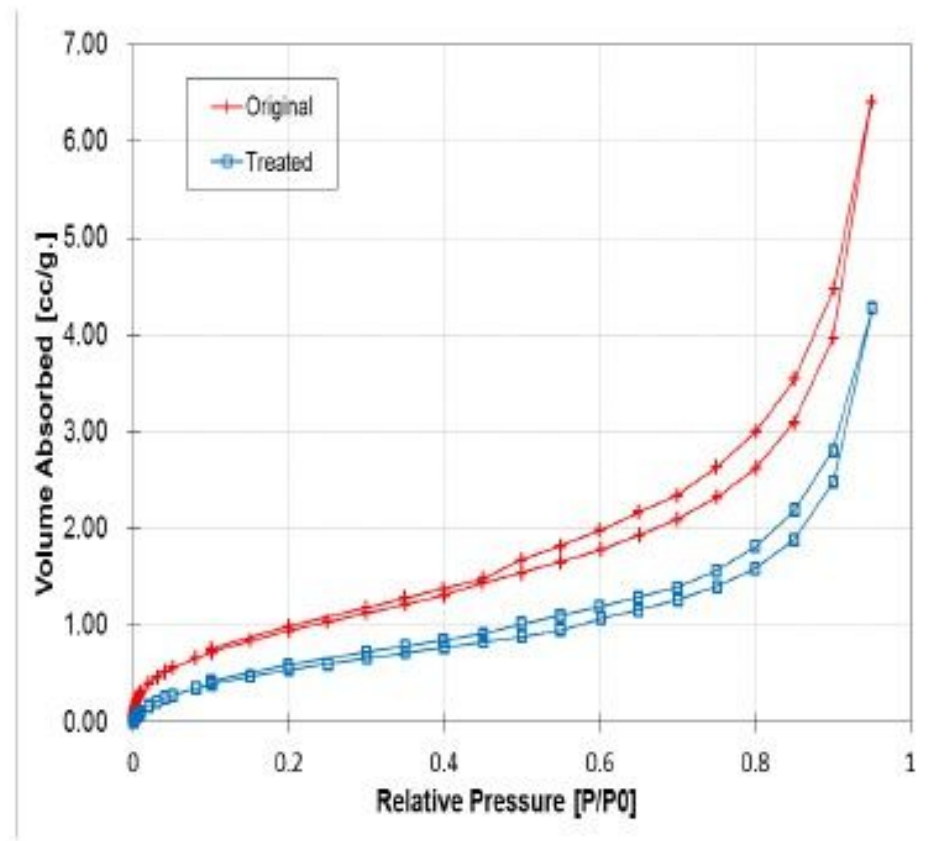

(b)

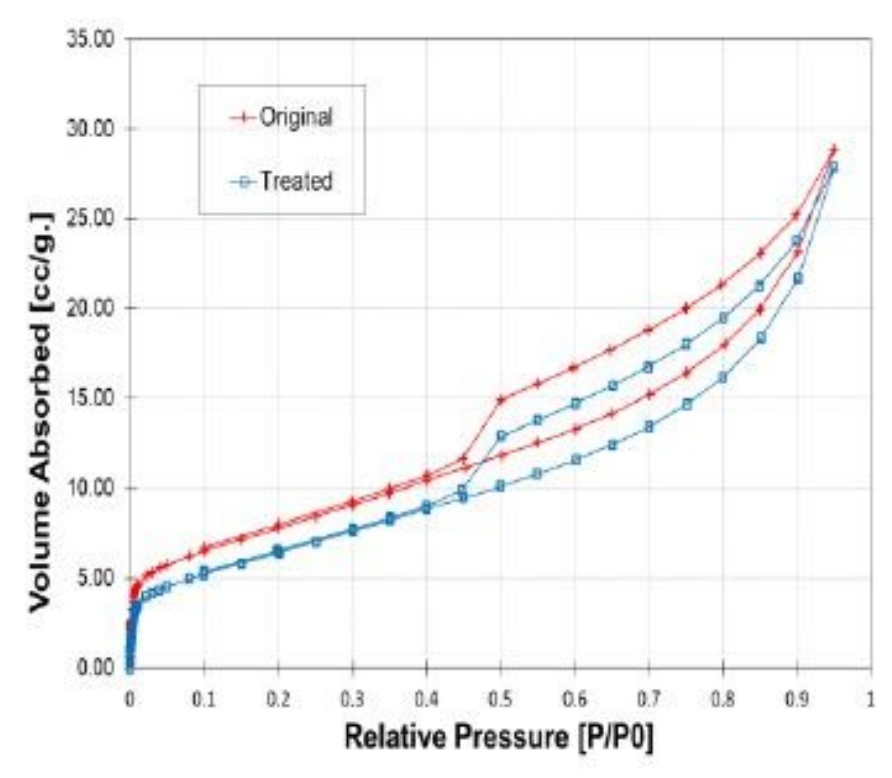

(d)

Figure 7

Isotherm Comparison for four shales tested (a) Haynesville, (b) Eagle Ford Shale, (c) Longmaxi Shale, and (d) Opalinus Shale 


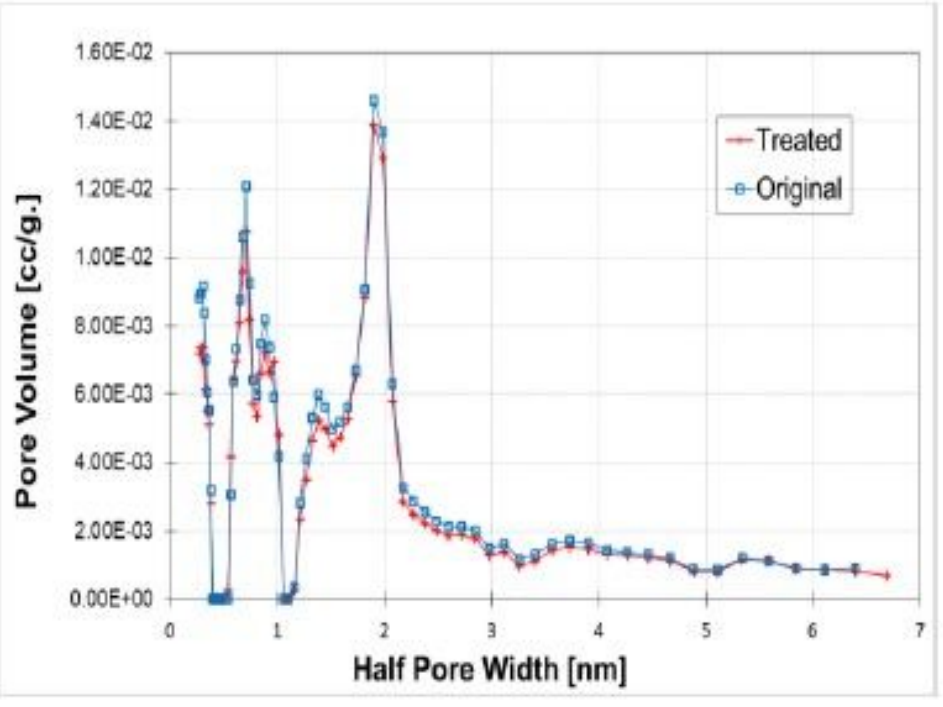

(a) Haynesville Shale

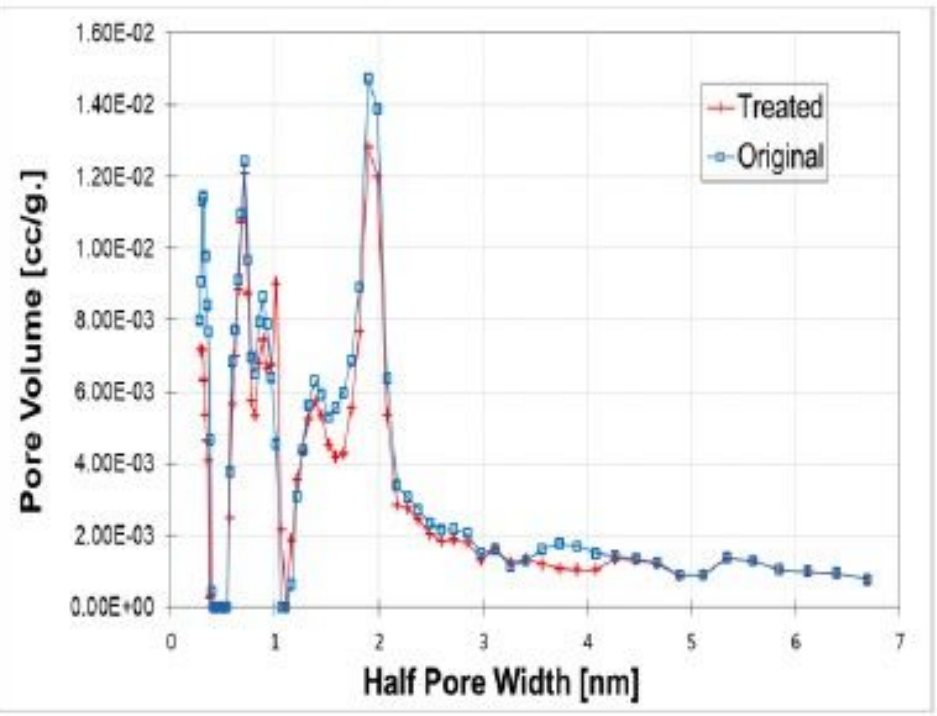

(c) Longmaxi Shale

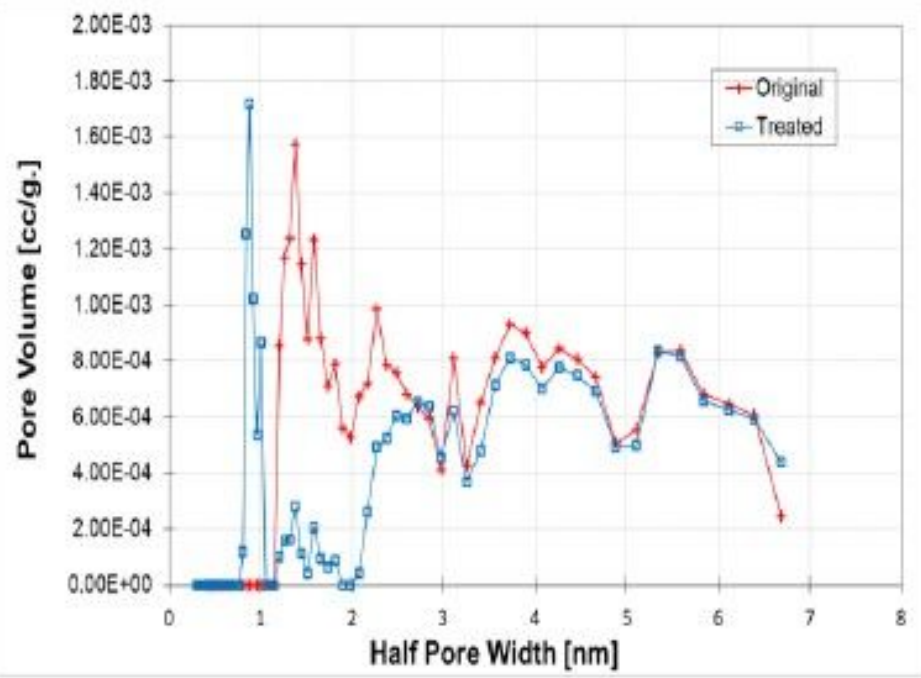

(b) Eagle Ford Shale

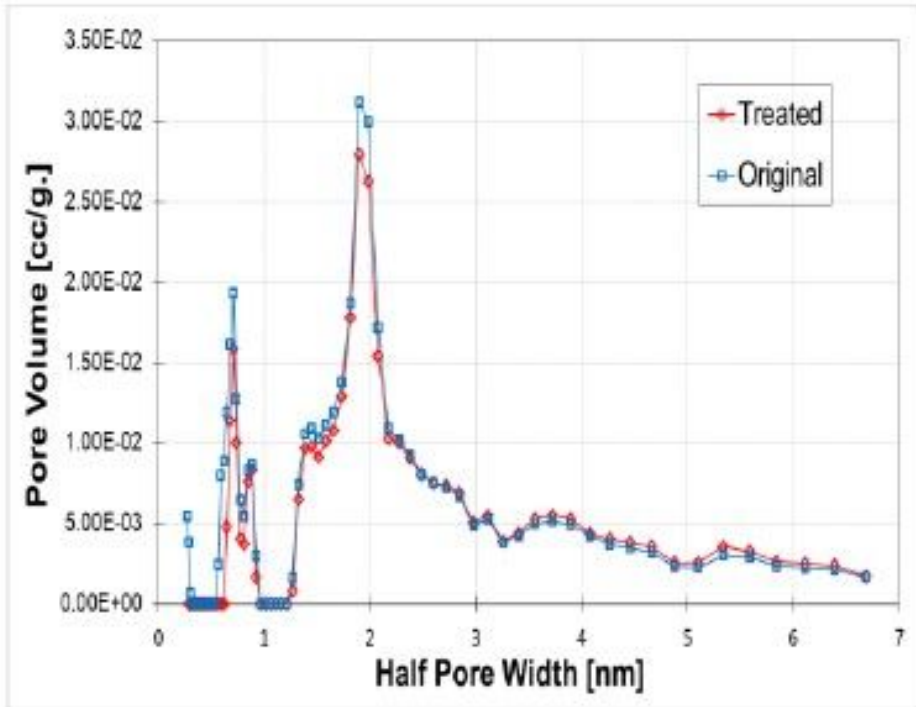

(d) Opalinus Shale

\section{Figure 8}

Pore size distribution comparison before and after treatment for four shales (a) Haynesville, (b) Eagle Ford Shale, (c) Longmaxi Shale, and (d) Opalinus Shale 


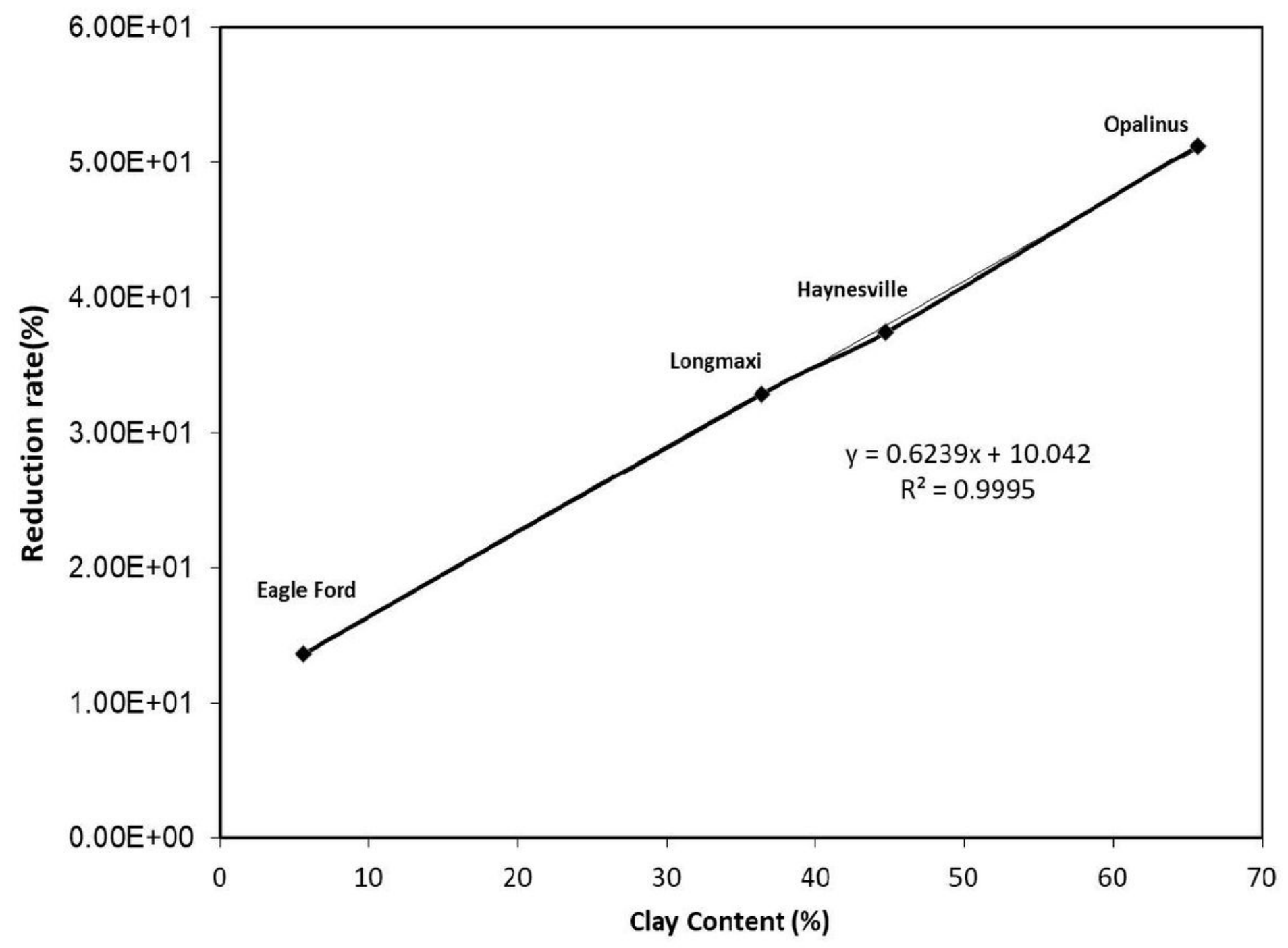

Figure 9

Correlation between clay content and porosity loss 

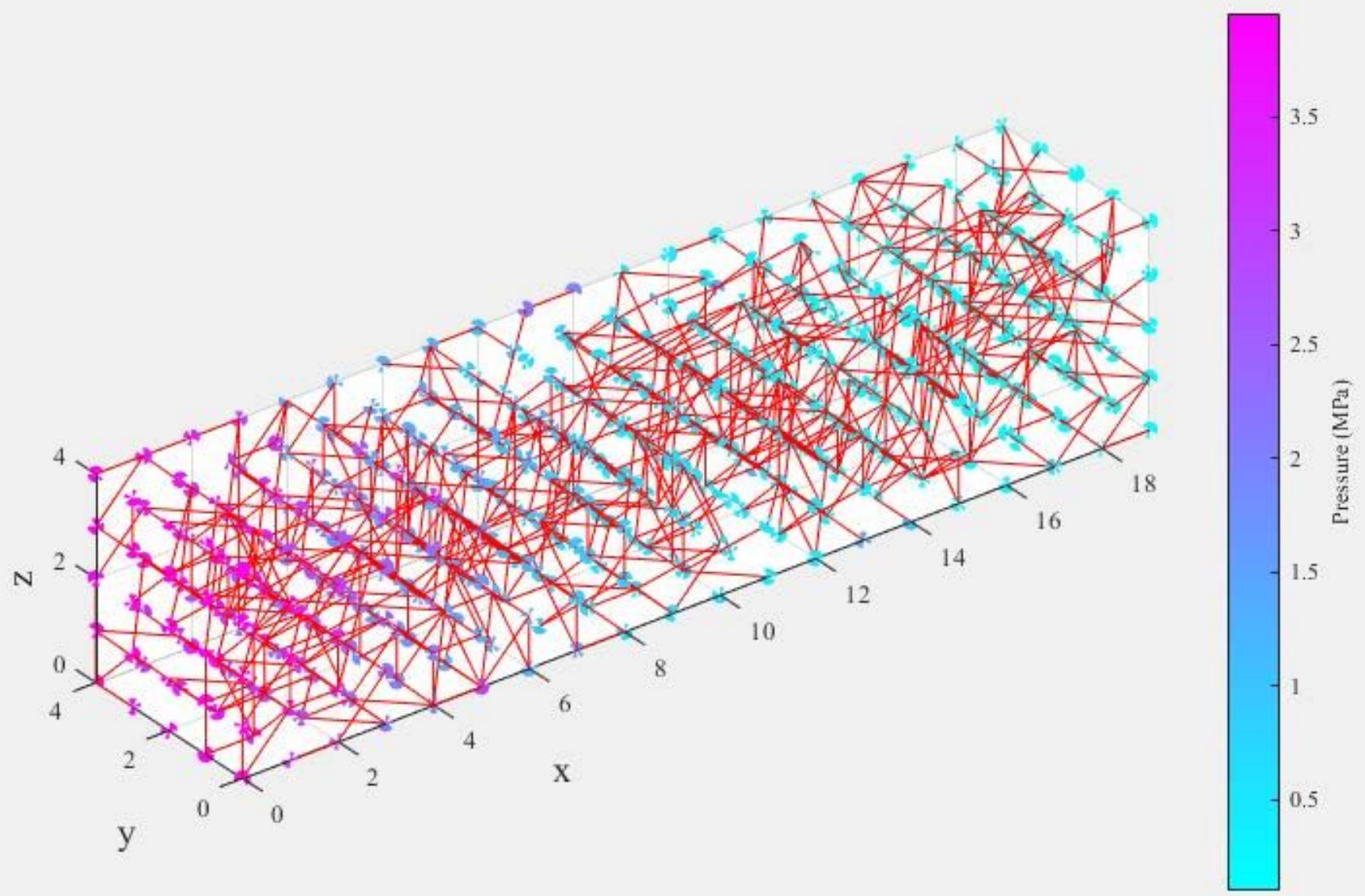

Figure 10

Illustration of a swelling pore network 


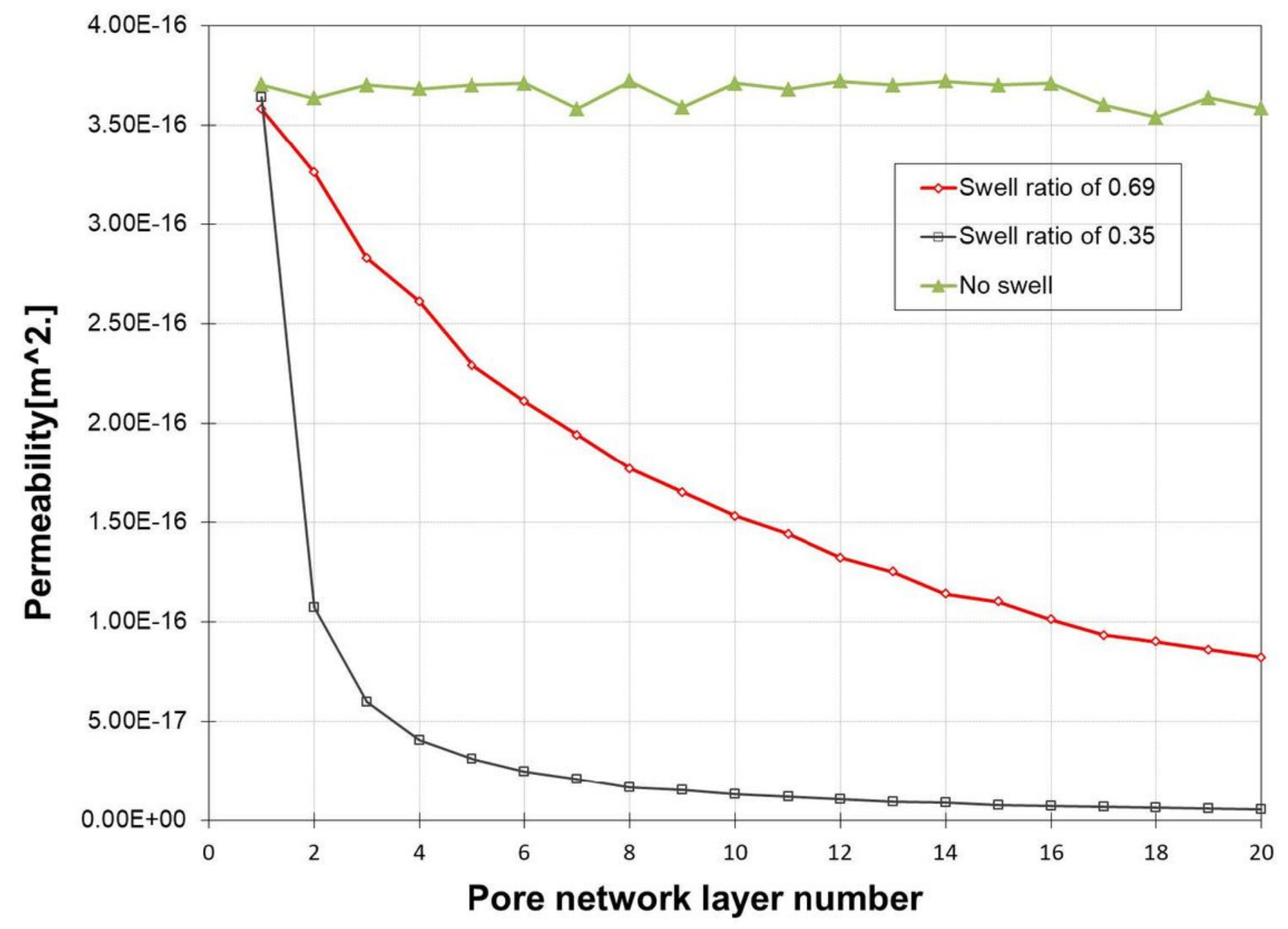

Figure 11

Impact of different swelling ratios on Permeability of Shale Matrix 


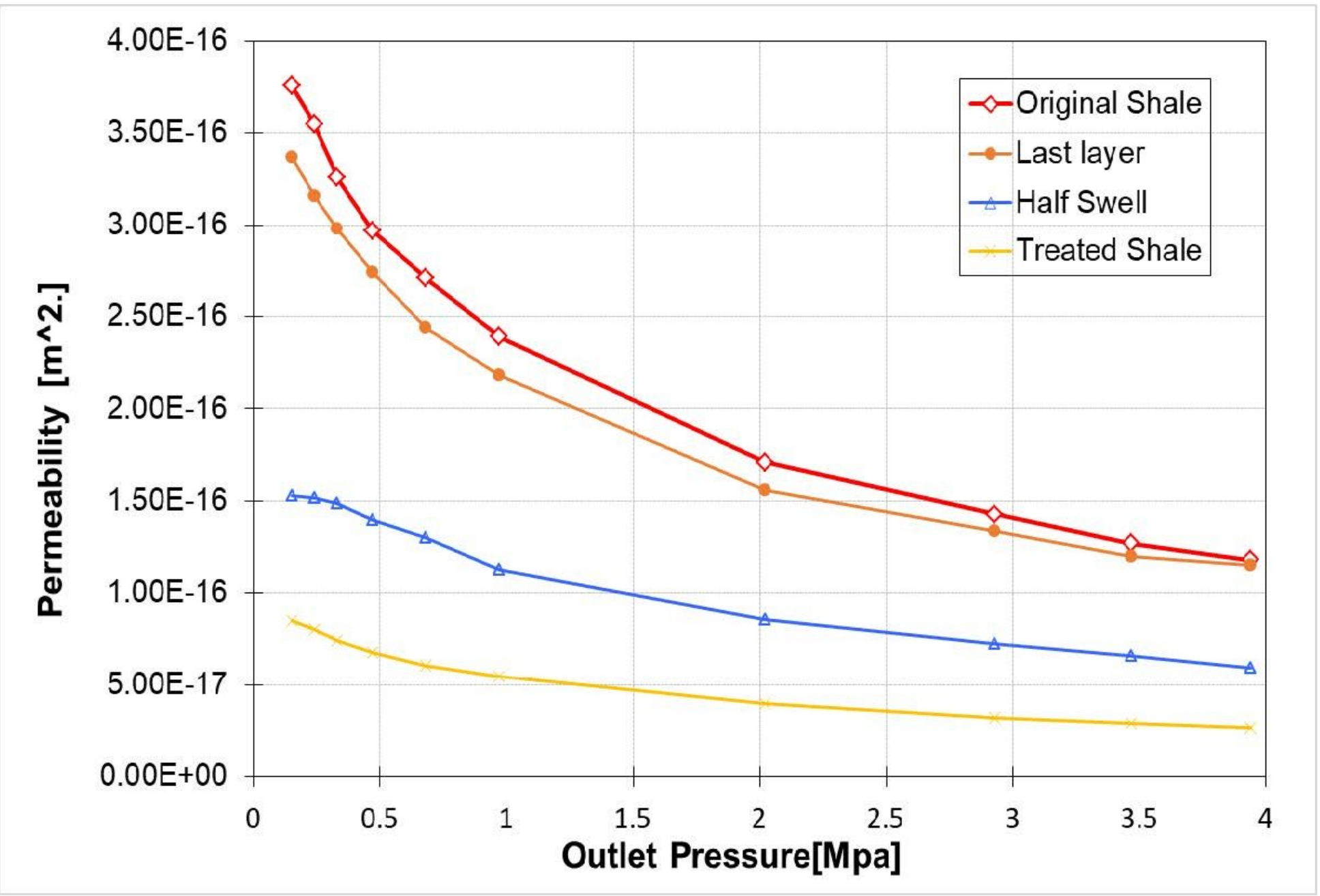

Figure 12

Permeability for different conditions of shale

\section{Supplementary Files}

This is a list of supplementary files associated with this preprint. Click to download.

- SupplementarydocumentFinal.pdf 